\title{
Reconnaissance Geology of the Upper St. John and Allagash River Basins, Maine
}

GEOLOGICAL SURVEY BULLETIN 1406

Work done in cooperation with the

Department of the Army',

New England Dizision.

Corps of Enginecrs

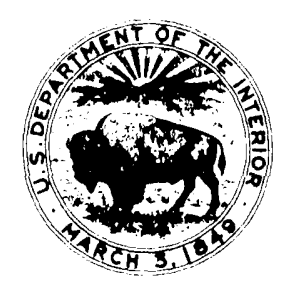





\section{Reconnaissance Geology of the Upper St. John and Allagash River Basins, Maine}

By EUGENE L. BOUDETTE, NORMAN L. HATCH, JR., and DAVID S. HARWOOD

GEOLOGICAL SURVEY BULLETIN 1406

Work done in cooperation with the

Department of the Army,

New England Division,

Corps of Engineers

Description of the geology of a glaciated

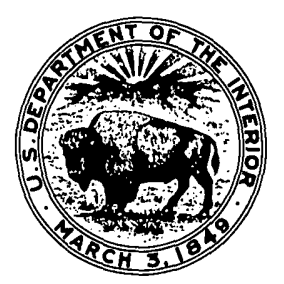
terrane of lower Paleozoic rocks in northern Maine with generalizations on exploration geochemistry and engineering materials 


\section{UNITED STATES DEPARTMENT OF THE INTERIOR}

THOMAS S. KLEPPE, Secretary

GEOLOGICAL SURVEY

V. E. McKelvey, Director

Library of Congress Cataloging in Publication Data

Boudette, Eugene L

Reconnaissance geology of the upper St. John and Allagash River Basins, Maine.

(U. S. Geological Survey bulletin ; 1406)

Bibliography: p.

Supt. of Docs. no.: I 19.3:1406

1. Geology-St. John River watershed. Me. and N. B. 2. Geology-Maine-Allagash River watershed. I. Hatch, Norman L., joint author. II. Harwood, David S., joint author. III. Title. IV. Series: United States. Geological Survey. Bulletin ; 1406. QE75.B9 no. 1406 [QE120.S2] $557.3^{\prime} 08$ s [557.41'1] 75-619316

For sale by the Superintendent of Documents, U.S. Government Printing Office Washington, D.C. 20402

Stock Number 024-001-02820-4 


\section{CONTENTS}

Page

Metric-English equivalents -

Abstract - _.

Introduction - -

Paleozoic stratigraphy _._.

Paleozoic stratified rocks, undivided: "Lac Landry sequence" -... 5

Cambrian and Ordovician rocks, undivided: "Estcourt Road sequence" -

Middle Ordovician rocks: "Depot Mountain sequence"

Upper Silurian rocks: "Fivemile Brook sequence"

Silurian or Devonian rocks: Strata of the Rocky Brook terrane 17

Silurian and Devonian orthoquartzite unit: "Hafey Mountain sequence" -

Seboomook Formation _._. 21

Priestly Lake stock

Quaternary deposits and features

Glacial drift

Outwash and ice-contact deposits 25

Structure -

Faults -

Folds

Minor structural features

Photolinears _.

Construction material

Dimension stone

Aggregate _._.

Riprap and coarse fill _._. 32

Sand and gravel

Stream-sediment geochemistry _._.

Heavy metals and copper

Mercury -... 33

Rock geochemistry _. 34

Selected references

\section{ILLUSTRATIONS}

Plate 1. Reconnaissance bedrock geologic map of the upper St. John and Allagash River basins, Maine ................ In pocket

2. Map showing selected features of the surficial geology, photolinears, construction materials, and heavy-metal content of stream sediment in the upper St. John and Allagash River basins, Maine -........ In pocket 
FIGURE 1. Index map showing location of the upper St. John and Page Allagash River basins, Maine, and area of reconnaissance

\section{TABLES}

TABLE 1. Columnar section of the Paleozoic rocks in the upper St.

John and Allagash River basins, Maine

Page

2. Estimated modes of sedimentary rocks from selected units

3. Estimated modes of volcanic and plutonic rocks from selected units

4. Rapid 6-step spectrographic analyses and instrumental mercury analyses of selected rocks from the upper St. John basin, Maine 
CONTENTS

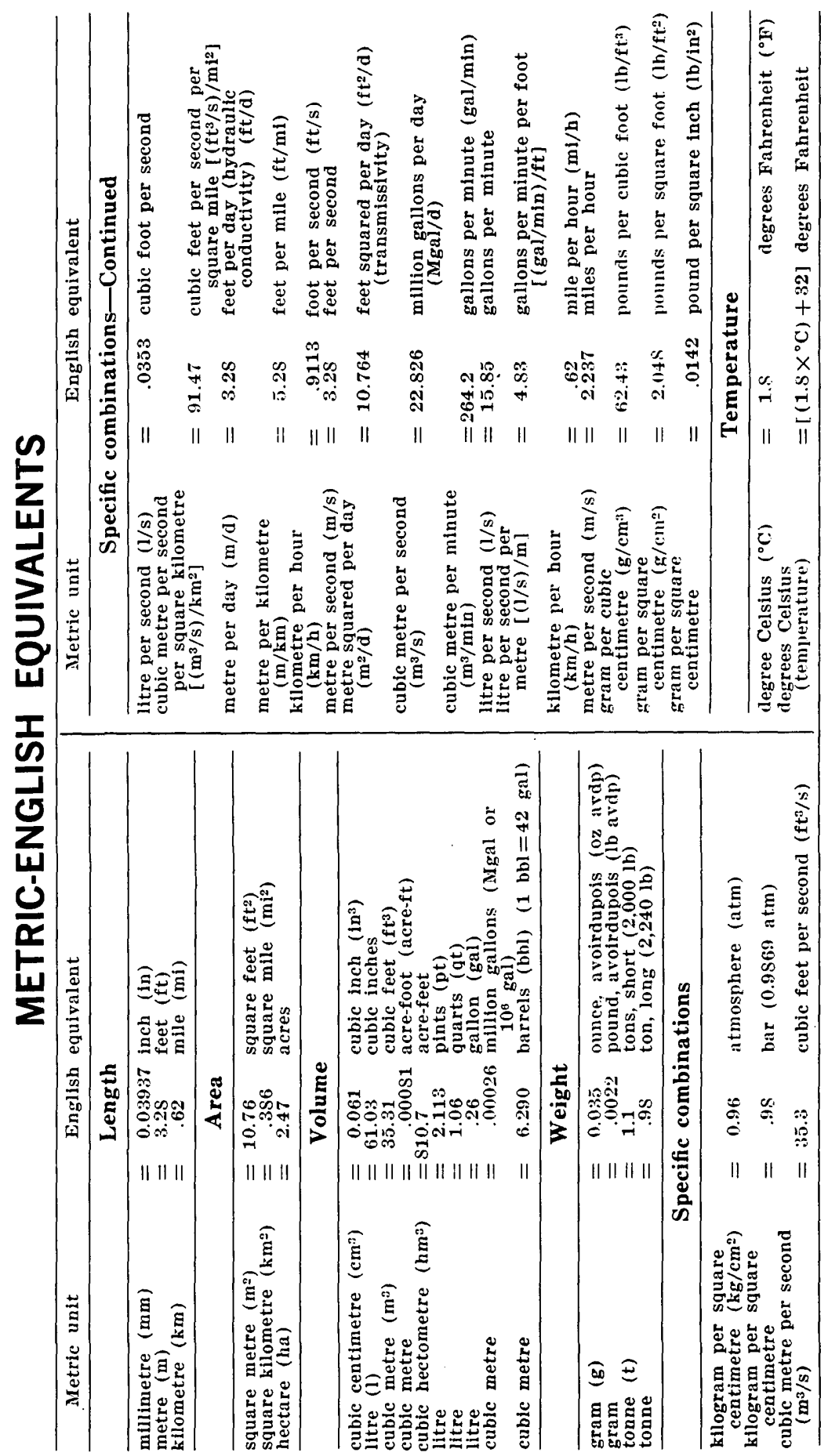





\title{
RECONNAISSANCE GEOLOGY OF THE UPPER ST. JOHN AND ALLAGASH RIVER BASINS, MAINE
}

\author{
By Eugene L. Boudette, Norman L. Hatch, Jr., \\ and David S. HaRwood
}

\begin{abstract}
Reconnaissance of $4,250 \mathrm{~km}^{2}$ in the St. John River basin and the northwest side of the Allagash River basin north of latitude $46^{\circ} 30^{\prime}$ and upstream from St. Francis, Maine, has shown the region to be underlain by low-grade regionally metamorphosed sedimentary and volcanic rocks and a small granodiorite stock. The layered rocks are on the southeast flank of the Green MountainSutton Mountain anticlinorium which extends from Vermont to southeastern Quebec, and are divided into six major stratigraphic units ranging in age from probable Cambrian to Early Devonian. A wide variety of predominantly eugeosynclinal, with some miogeosynclinal, rocks occurs in different proportions or as the characterizing rock types in the different mapped units. The units occur in northeast-trending belts 1.5 to $40 \mathrm{~km}$ wide. Fossils from seven localities date some of the layered rocks as (1) Middle Ordovician, (2) Late Silurian, (3) Silurian(?), and (4) Early Devonian. The Middle Ordovician unit is believed to be the temporal equivalent of the Beauceville Formation of Quebec, and the Early Devonian rocks are considered as coeval and coextensive with the Seboomook, St. Juste, and Temiscouata Formations of Maine and Quebec. A granodiorite stock, about $8 \mathrm{~km}^{2}$ in area, discordantly intrudes Lower Devonian rocks and is surrounded by a contact metamorphic aureale of cordierite-biotite-andalusite hornfels.

Bedrock is blanketed with a relatively thin deposit of glacial drift over most of the region. Small outwash deposits are scattered; a few larger deposits occur in the north and along major stream courses.

Layered rocks are deformed to varying degrees by folds and are cut by cleavage and by faults. Minor folds are abundant in all rocks, but larger folds were recognized only in Lower Devonian rocks. A large folded thrust slice and a large magnitude reverse fault subordinate to the thrust are inferred from interrupted homoclinal sequences, repeated stratigraphy, and lineaments. Several other subordinate faults are indicated by truncated and offset beds.

The region contains large potential resources of dimension stone, aggregate, riprap, coarse fill, impervious fill, and sand and gravel. Anomalous values of copper, and possibly mercury, in stream sediments (mostly in the southern part of the area at elevations over $290 \mathrm{~m}$ ) are indicated by preliminary geochemical studies. Hydrothermal pyrite was found in conglomerate at Depot Mountain; spectrographic analysis showed no appreciable heavy-metal values associated with the pyrite.
\end{abstract}




\section{INTRODUCTION}

A geologic reconnaissance of the upper St. John and Allagash River basins in extreme northern Maine was made during the fall of 1966 (fig. 1). The area of study encompassed about $4,250 \mathrm{~km}^{2}$ north of latitude $46^{\circ} 30^{\prime}$, west and upstream of the village of Allagash at the confluence of the two rivers, and entirely within the State of Maine. Except for small parts of Piscataquis and Somerset Counties, the area is within Aroostook County. St. Francis, Allagash, and Dickey, all in Allagash Township, are the only permanent settlements in the area.

The area is almost entirely forested; only a few square kilometres of open farm land are present along the major streams. Relief in the region is variable. (See pl. 1.) In the northeast, mountains such as Rocky and McLean Mountains, which have a relief of about $300 \mathrm{~m}$, are as high as about $600 \mathrm{~m}$, although most summits are between 400 and $500 \mathrm{~m}$ high. To the southwest, the terrain is more gently rolling but has local prominences such as Depot Mountain $(450 \mathrm{~m})$ and Priestly Mountain $(579 \mathrm{~m})$.

Both the St. John and the Allagash Rivers drain northeast; most of their tributaries flow southeast or northwest.

Access to the area is limited. The only State road is Highway 161 that follows the St. John River from Fort Kent and terminates at Dickey. Otherwise, access is restricted to a relatively few private and temporary lumbering roads and assorted jeep trails and winter roads that are passable, if at all, only by 4 -wheel-drive vehicles. The principal routes of entry to the area are from Allagash, Maine, and St. Joseph de la Rivière Bleue, Estcourt, St. Pamphile, and Lac Frontiere, Quebec. (See pl. 1.) Use of many of these roads requires prearrangement with landowners. A few of the larger streams are suitable for travel by canoe at certain times of year. The larger ponds and river deadwaters can be used for landing float planes.

Lumbering is the principal industry of the region; both multiple-use $\operatorname{logs}$ and pulpwood are produced and are exported to Canada and transported elsewhere in Maine. Canoeing, especially on the Allagash State Riverway, hunting, and fishing provide some recreational industry in the region.

The earliest geologic investigations in the region were carried out by Jackson (1838), Hodge (1838), Hitchcock (1861a, b; 1862), Bailey (1887), Bailey and McInnes (1888, 1893), and McGerrigle (1934). Wing (1951) traversed the major water courses, and Boucot (1961) traced the extent of the Silurian and Devonian rocks through the area from the southwest. Boucot and others (1964) compiled geologic and aeromagnetic data over much 


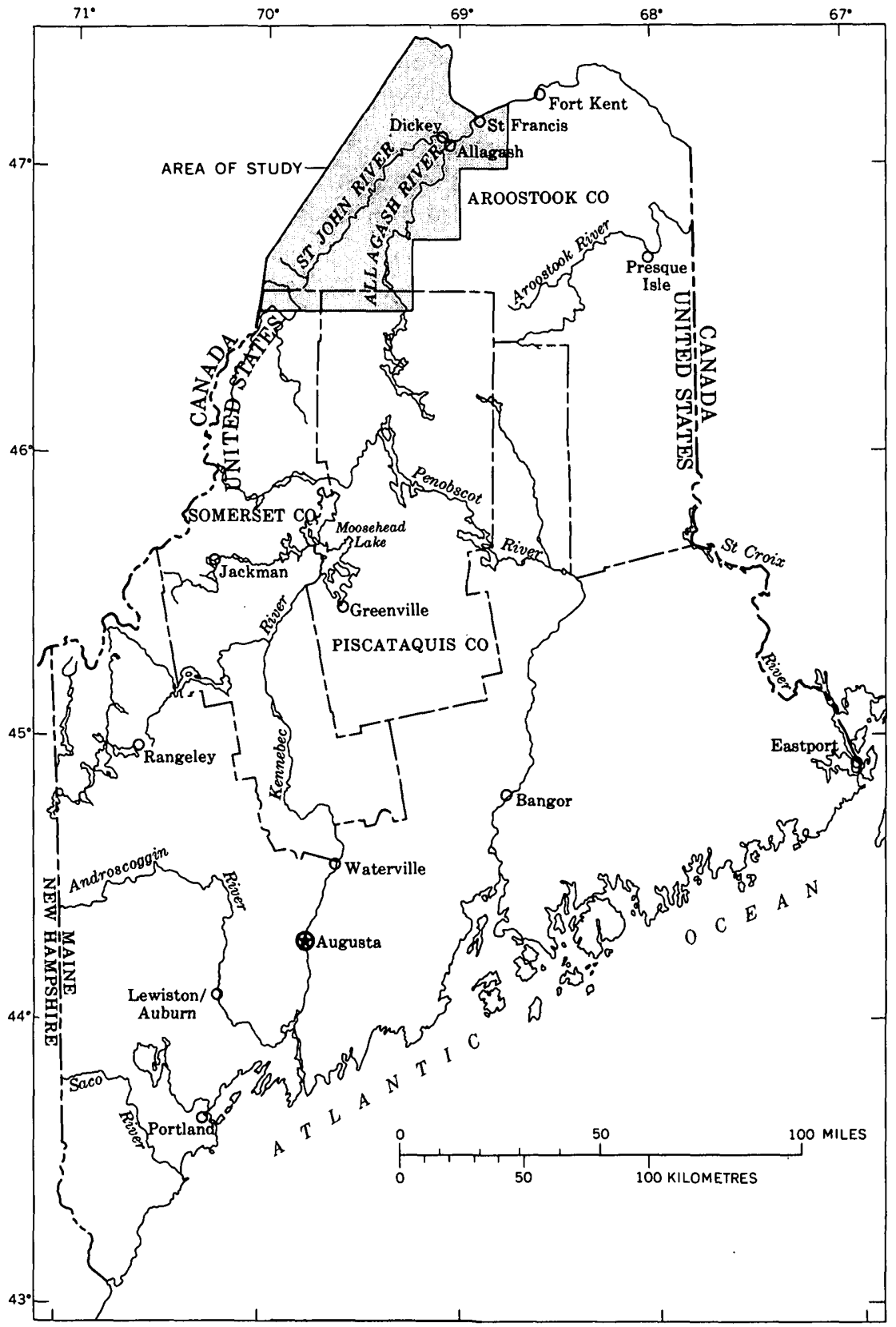

Figure 1.-Index map showing the location of the upper St. John and Allagash River basins, Maine, and area of reconnaissance mapping. 
of the area. The unpublished results of reconnaissance by Louis Pavlides in the northeastern part of the region in 1951 and by R. B. Neuman in 1963 have supplemented the present work.

Béland (1957, 1962), Lespérance (1960), and W. A. Gorman (unpub. data) carried out investigations in adjacent areas in Quebec that have direct bearing on the present study and summarize the pertinent earlier Canadian work.

Reconnaissance mapping of the region for this investigation was done in August and September 1966 in cooperation with the Department of the Army, New England Division, Corps of Engineers as part of the "Upper St. John River Water Resources Development Program." The fieldwork was done largely by traversing by means of 4 -wheel-drive vehicles over lumber company access roads, winter roads, and jeep trails and was supplemented by foot traversing in critical areas. Outcrops in much of the region are scarce, but because glacial cover is thin, bulldozing along roads has exposed many critical ones.

Several colleagues contributed to our work. R. B. Neuman, A. J. Boucot, W. A. Oliver, Jr., F. C. Canney, and E. V. Post of the Geological Survey have contributed fossil determinations and analytical services. We are indebted to Boucot and Oliver for identification of Silurian and Devonian fossil forms. Neuman contributed critical fossil data on a Silurian or Devonian locality he found near Campbell Depot. We are also particularly indebted to H. A. Verville and R. C. Gurley of the New England Division, Corps of Engineers, who aided the authors in planning the work, visited the field, and provided helpful discussions in interpreting data. The manuscript was reviewed by L. R. Page, Louis Pavlides, and G. H. Espenshade, who substantially improved it.

Mr. Ronald Simon, Chief Warden, Allagash District, Maine Forest Service, and the area wardens of his staff gave freely of their time to assist the authors in many logistical details and made available to us the facilities of the Maine Forest Service in the region. The success of the reconnaissance is in large measure attributable to the wholehearted cooperation and interest of these men. The authors also gratefully acknowledge the cooperation and help of Albert Baker of the Seven Islands Co., St. Pamphile, Quebec., and M. R. Wing and Carl Holden of the International Paper Co.

Jay D. Murray and Russell G. Clark, Jr., provided able assistance in the field. 


\section{PALEOZOIC STRATIGRAPHY}

The stratified rocks of the area have been divided into eight lithostratigraphic units (table 1). Because of the reconnaissance nature of the mapping, the only formal stratigraphic name applied to rocks in the area is Seboomook Formation, although correlations are proposed for the other units.

The unnamed units are provisionally regarded as at least equivalent to formations (see table 1), some of which can be subdivided into members. We have informally called these units "sequences" and "strata of the Rocky Brook terrane" for convenience of discussion and correlation with table 1 only; no stratigraphic nomenclature is intended at this time. Although all of these rocks have been regionally metamorphosed to at least the chlorite zone, the nomenclature of sedimentary rather than metamorphic rocks is used in most cases because the original sedimentary textures and character are largely preserved. Stratigraphic thicknesses for nearly all units are only estimates because the amount of tectonic thickening resulting from faulting or folding is not known. Thickness estimations that assume homoclinal sequences for units are maximum values; pretectonic thicknesses, in some places, could be considerably less.

\section{PALEOZOIC STRATIFIED ROCKS, UNDIVIDED: "LAC LANDRY SEQUENCE"}

\section{LITHOLOGY}

Interbedded orthoquartzite, slate, graywacke, ${ }^{1}$ and sandstone in about equal amounts underlie the extreme northwest part of the region (pl. 1). The age of these rocks is not known, but they are presumed to be of Paleozoic age. These rocks, which can be traced across the international boundary into Quebec, are here called "Lac Landry" for that feature on the northwestern side of the unit in Quebec (pl. 1). The sequence is well exposed on lumbering roads that cross the highlands west of the main access road (called "Irving Road") which extends south into Maine from Oak's farm (about $6.4 \mathrm{~km}$ southwest of Estcourt, Quebec).

The stratigraphy of the sequence is not known, but a variety of rock types including orthoquartzite, graywacke, laminated sandstone, and slate is present.

Orthoquartzite is light gray on fresh surfaces, medium to coarse grained, and occurs in beds about 1 to $3 \mathrm{~m}$ thick. It commonly weathers gray white with limonite coatings on fractures. A dis-

1 Graywacke is used here as defined by Gilbert (Williams and others 1954, p. 289-294). 


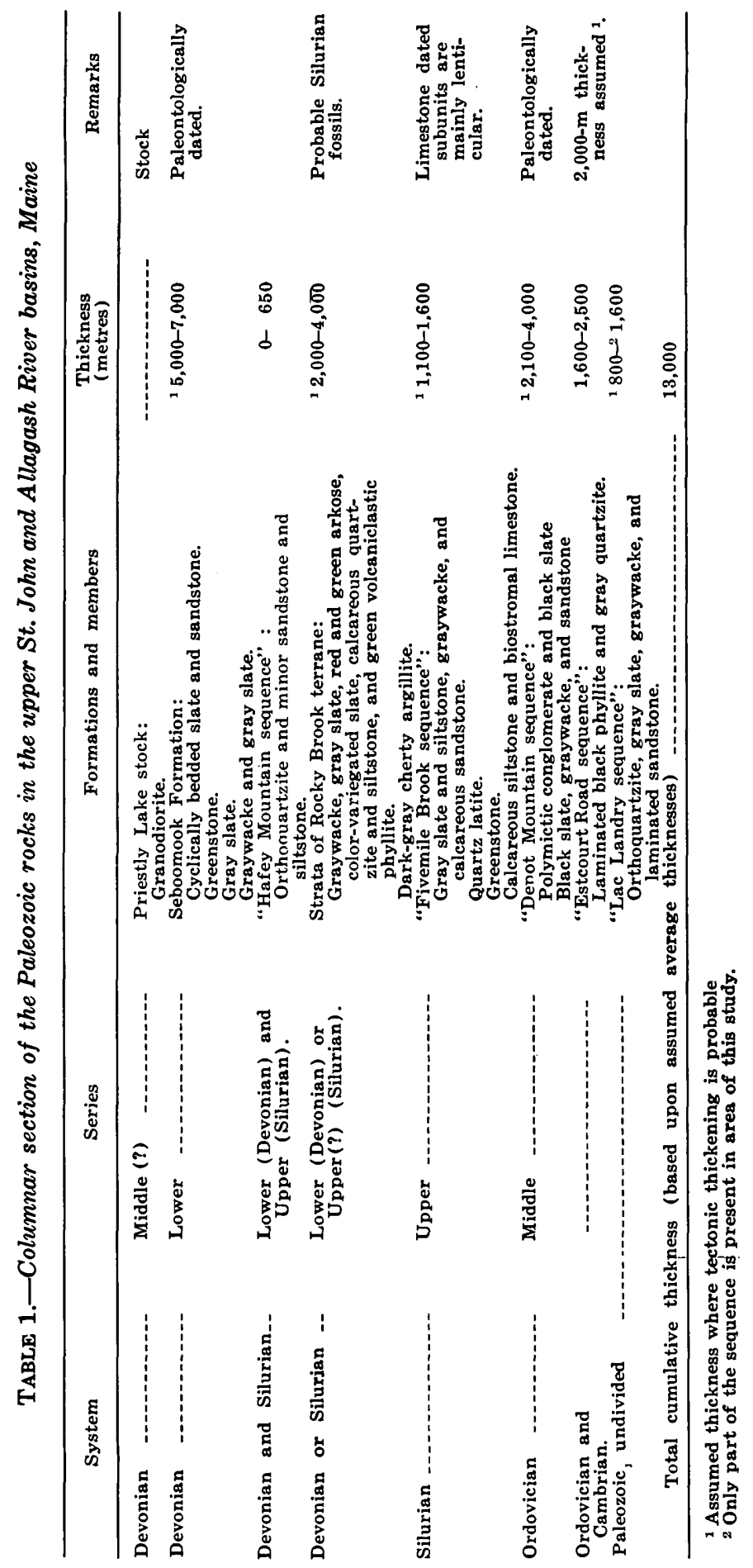


tinctive close-spaced boxwork of quartz veins, 0.5 to $5 \mathrm{~cm}$ thick, cuts the orthoquartzite. Macroscopically, the orthoquartzite appears to be composed almost entirely of quartz grains; locally "pea gravel" quartz and minor slate chips are present. Bedding is difficult to distinguish in the quartzite, but a faint lamination is present in some outcrops. Thin sections show the rock to be more than 95 percent strained and unstrained detrital quartz; minor amounts of detrital untwinned feldspar, muscovite, amphibole, and zircon are present. Limonite is a relatively abundant secondary mineral. Quartz grains are sutured, and feldspar is partially altered to mica and clay. Mixtures of sericite and quartz occur along fracture cleavage planes that commonly break across grains. Late quartz-pyrite veinlets that cut the rock contain pyrite, mostly altered to limonite.

Sandstone is light brown to light gray on fresh surfaces. It is medium to very fine grained, silty, and characterized by laminated thin beds about $8 \mathrm{~cm}$ thick. The lamination results from variation in quartz content. In upper Rocky Brook, white mica, shown to be detrital by its textural relationships with other clastic and matrix minerals, occurs locally, and sulfide minerals are present. The rock weathers rusty, especially where adjacent to the orthoquartzite.

Slate is dark gray, weathers light gray, and appears uniformly very fine grained. Bedding is not conspicuous, but layers about 0.6 $m$ thick are present at one place.

Graywacke is dark green gray and fine to coarse grained; clasts of quartz are much more abundant than clasts of feldspar. The rock weathers chalky white and is relatively massive; beds average more than $1 \mathrm{~m}$ thick. It is macroscopically identical with graywacke found in the undivided unit of Silurian or Devonian rocks of the Rocky Brook terrane described later. The thickness of the undivided Paleozoic unit is estimated to be slightly more than $1,250 \mathrm{~m}$.

\section{AGE AND GORRELATION}

The correlation of the unit presents less of a problem than the age. Béland (1957) mapped, as the Rosaire Group, a sequence of rocks that is lithologically identical with our Paleozoic undivided unit. He assigned a Cambrian age to the Rosaire Group on the basis of long-range regional correlations. Directly to the north and northeast, our Paleozoic undivided unit is traceable into rocks that were mapped by W. A. Gorman (unpub. reports; written commun., January 1967) as Rosaire Group of Béland and Caldwell Group of MacKay (1921) (Armagh of Béland). In the Temis- 
couata Lake region farther northeast, similar rocks were assigned to the Quebec Group (Cambrian (?) and (or) Ordovician) by Lespérance (1960). If the correlation with the Rosaire Group of Béland is valid and if the Rosaire is Cambrian, the "Lac Landry" sequence contains the oldest rocks in the study area.

\section{CAMBRIAN AND ORDOVICIAN ROCKS, UNDIVIDED: "ESTCOURT ROAD SEQUENCE"}

The "Lac Landry" sequence is surrounded on the map (pl. 1) by a unit characterized by abundantly sulfidic interbedded phyllite and quartzite, called "Estcourt Road" for the access route which traverses it. These rocks are exposed in several places along this road, which enters the area from Estcourt, Quebec.

\section{LITHOLOGY}

A distinctive striping caused by intercalation of dark- and lightgray phyllite and quartzite is common in this unit. The ratio of phyllite to quartzite is variable from outcrop to outcrop, as is the thickness of beds, which ranges from about 0.5 to $5 \mathrm{~cm}$. Both the phyllite and quartzite beds are characteristically laminated; locally, the quartzite shows good "pinstripe" lamination, and the phyllite is cherty. Quartz veins and silicified rock are locally abundant. The rock is characteristically intensely deformed by small isoclinal folds, fracture and slip cleavage, and boudinage of quartzite beds.

The phyllite is strongly foliated and very fine grained. It is composed of clastic material in a lepidoblastic sericite-chlorite matrix. The muscovite is recognized as detrital in this and other rocks from textural criteria: its imbricate relationship to other clasts and sharp delineation from the matrix, its abraded edges, and its lack of metamorphic-growth features on borders. The estimated mode for average phyllite is given in table 2. Microscopically spaced flow and fracture cleavage are present in the rock.

The quartzite is very fine grained and contains only minor amounts of lepidoblastic sericite in ragged secondary growths that occur with chlorite and limonite along poorly developed fracture cleavage planes. Biotite is recognized as detrital by the same criteria used for detrital muscovite in phyllite and other rocks. The early-formed cleavage planes commonly show offset and folding on later slip cleavage. The estimated mode for a typical quartzite is given in table 2 .

The thickness of the undifferentiated Cambrian and Ordovician unit is not precisely known, but it is estimated to be between 1,600 to $2,600 \mathrm{~m}$. 


\section{AGE AND CORRELATION}

The undifferentiated Cambrian and Ordovician unit is lithologically similar to rocks that Béland $(1957,1962)$ mapped as the Armagh Group and Caldwell Group of MacKay (1921) and believed to be Cambrian in age; only the Caldwell is on regional strike. Béland $(1957,1962)$ was uncertain of the position of his Armagh Group, but inferred that it is older than his Rosaire Group. He considered the Caldwell Group to be younger than the Rosaire. W. A. Gorman (unpub. reports; written commun., Jan. $17,1967)$ mapped rocks continuous along strike to the northeast as Caldwell of MacKay (1921); he believed that the Armagh Group of Béland and the Caldwell are essentially equivalent. These same units farther to the northeast in the Temiscouata Lake region were lumped with equivalents of the Rosaire Group of Béland and ascribed to the Quebec Group (Lespérance, 1960) (see section above). Some relatively young rocks that are equivalent to the Middle Ordovician Beauceville Group of MacKay (1921) (see also Gorman, 1955, and Béland, 1957) may be included in the undivided Cambrian and Ordovician unit of this report.

Within the map area, the age assignment of the undivided Cambrian and Ordovician unit is supported by three criteria:

1. Complex folding and cleavage patterns suggest that the rocks have been twice folded.

2. Quartzites commonly are finely laminated ("pinstripe").

3. The unit contains dark sulfidic pelitic rocks.

These criteria together commonly characterize stratified rocks of the northern Appalachians that are Middle Ordovician or older.

\section{MIDDLE ORDOVICIAN ROCKS: "DEPOT MOUNTAIN SEQUENCE"}

Dark-gray to black sulfidic slate, graywacke, feldspathic sandstone, and polymictic conglomerate compose a distinctive unit 1.5 to $5 \mathrm{~km}$ wide that has been tentatively traced for about $110 \mathrm{~km}$ from Depot Stream on the southwest to Jones Brook on the northeast. The sequence is called "Depot Mountain" for the mountain where the section is most completely exposed and fossil dated.

\section{LITHOLOGY}

The stratigraphic sequence of the "Depot Mountain" and the nature of its contacts with older and younger units are not well known. In the southwestern part of the region near Depot Mountain, the sequence of rock types from northwest to southeast is rusty-weathering sooty-black slate, polymictic conglomerate, and 
TABLE 2.-Estimated modes of sedimentary [If minerals were not found or if identification is

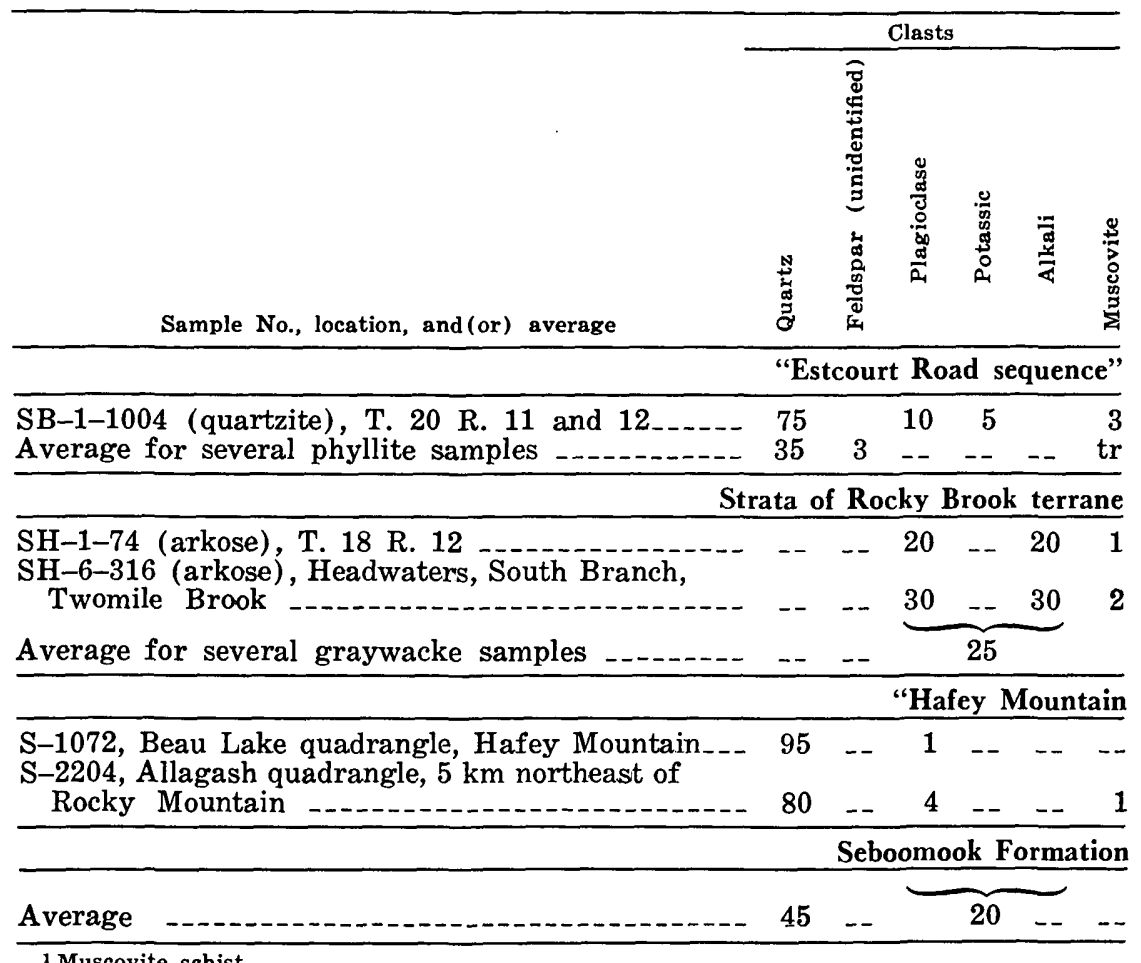

${ }^{1}$ Muscovite schist.

a unit of mixed graywacke, black and green slate, and feldspathic quartzite. The polymictic conglomerate is well exposed on Depot Mountain and near Bruleau Pond. Dark-gray to sooty-black, rustyweathered, and soft, highly fissile sulfidic slate is the dominant lithology of the Middle Ordovician unit in the southwestern part of the area. Bedding is not common, but locally thin layers of lightgray to black, rusty-weathered sandstone as much as $5 \mathrm{~cm}$ thick are present in the black slate. These sandstone beds are generally tightly folded, and in one outcrop they show complex slump folds and convolutions characteristic of wet-sediment deformation.

Dark-green to greenish-gray, rusty-tan-weathered, fine- to meidium-grained graywacke makes up about 25 percent of the Middle Ordovician unit and is locally interbedded with thin beds and lenses of green and black slate. In places the graywacke is calcareous and has a punky-brown weathered rind about $1 \mathrm{~cm}$ thick.

In the northeastern part of the region, black slate and graywacke are interbedded in variable proportions, but graywacke pre- 
rocks from selected units (volume percent)

uncertain, no values are listed. Trace amounts shown as "tr"]

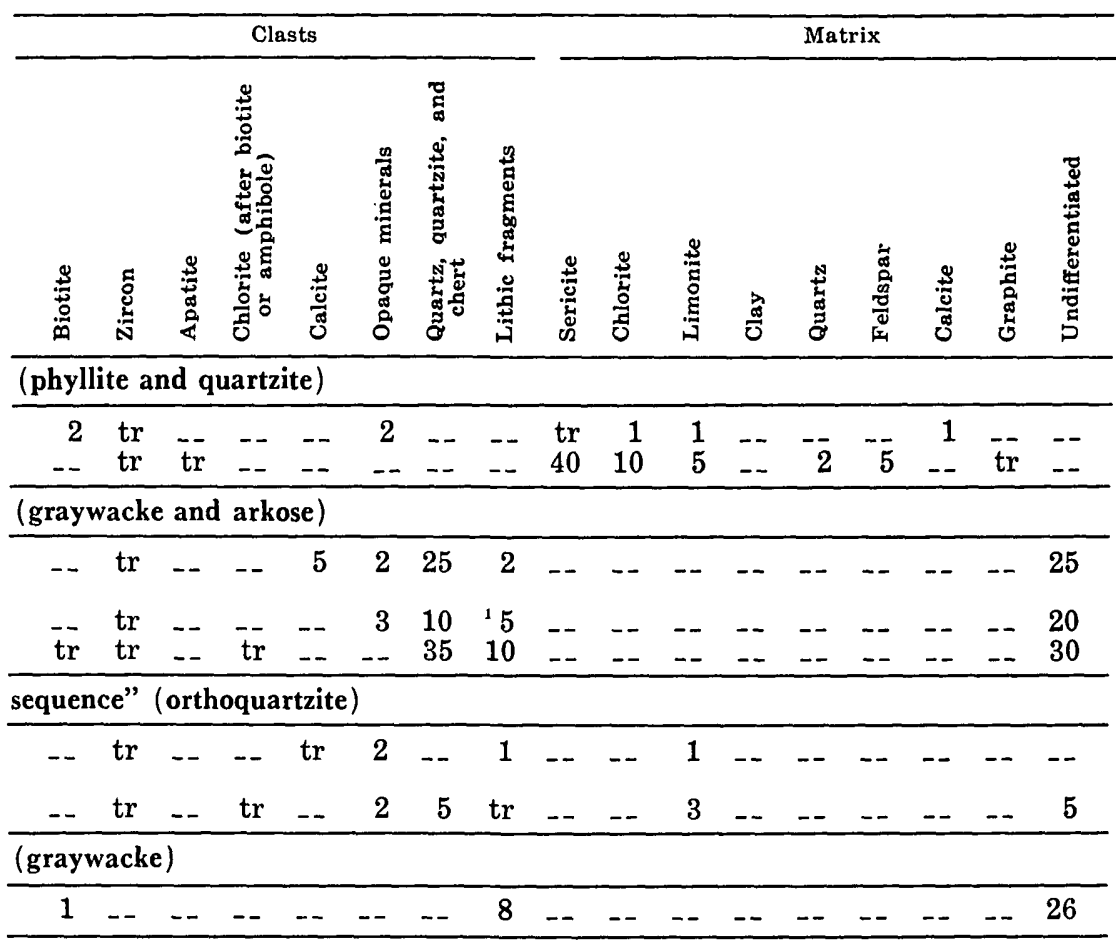

dominates on the northwestern side of the belt, and black slate is more common on the southeastern side. Polymictic conglomerate is exposed where the road to the camp at Boat Landing Mountain crosses Rocky Brook and in the road about $1.6 \mathrm{~km}$ north of the headwaters of Hafey Brook. Graywacke containing lenses of black and green slate is the dominant rock near Jones Brook.

Dark-gray, rusty-weathered, poorly sorted polymictic conglomerate in beds a few metres thick makes up a distinctive, possibly lenticular, unit in the Middle Ordovician unit. Clasts of gray quartzite, vein quartz, black and gray chert, felsite porphyry, green and black slate, and greenstone as much as $8 \mathrm{~cm}$ in diameter are contained in a fine- to medium-grained matrix composed predominantly of quartz, feldspar, and sericite. Locally, on the western slope of Depot Mountain, the conglomerate contains abundant pyrite. A spectrographic analysis of the pyritic conglomerate is given in a later section.

Bedding in the conglomerate is shown by an abrupt change in grain size or by a change in the ratio of matrix to clasts. On the 
west slope of Depot Mountain, lenses of black slate, as much as 0.3 $m$ thick, compose less than 10 percent of the conglomerate unit. Although the contact between the main mass of black slate and the conglomerate was not observed, the thin lens of slate in the coarse clastic rock suggests that the contact is gradational.

Middle Ordovician rocks in the region are locally as much as 5 $\mathrm{km}$ thick if the mapped contacts are correct and if the sequence is homoclinal and steeply dipping, as indicated by bedding observations. The polymictic conglomerate member is at most $800 \mathrm{~m}$ thick.

\section{AGE AND CORRELATION}

The black slate, graywacke, and polymictic conglomerate in the southern part of the region are on strike with the Beauceville Formation of MacKay as mapped by Béland (1957), and dated as late Middle Ordovician (Berry, 1962). Middle Ordovician graptolites (Berry, written commun., 1967) were found in black slate lenses in the conglomerate at fossil locality F-277 near Depot Mountain (pl. 1). No other fossils were found in the Middle Ordovician unit, but a Middle Ordovician age is inferred for the entire sequence on the basis of the lithologic similarity of the rocks in the northeast with the dated rocks in the southwest. If the Middle Ordovician age assignment of the rocks in the Rocky Brook-Yankeetuladi Brook area is correct, a problem arises in correlating the unit northeastward into the Lake Temiscouata area. On regional strike to the northeast and traceable to Lake Temiscouata are similar rocks that Lespérance (1960) mapped as part of his Cabano Formation (see also Lajoie and others, 1968) and to which he assigned an Early Silurian age on the basis of structural position below fossil-dated rocks. The conflicting age assignment cannot presently be resolved by means of the data available. The unit here considered to be Middle Ordovician could range in age from Middle Ordovician to as late as Late Silurian, the upper limit being imposed by the fossiliferous limestone described below.

\section{UPPER SILURIAN ROCKS: "FIVEMILE BROOK SEQUENCE" LITHOLOGY}

Gray slate, carbonate rocks, and felsic- to intermediate-volcanic rocks underlie a narrow northeast-trending belt that extends from Yankeetuladi Brook to Big Black River. This sequence is called "Fivemile Brook" for the stream in the southwest section which exposes all but the quartz latite member where the unit is dated. These rocks are divided (pl. 1) into (1) a gray slate unit; (2) medial volcanic rocks, subdivided into quartz latite lava in the 
northeast section and greenstone (metamorphosed andesite) in the southwest section; and (3) an undifferentiated calcareous siltstone and biostromal limestone unit. The slate and carbonate units probably grade into one another and are the most abundant lithologies in the sequence. The upper contact is probably gradational and is arbitrarily placed at the uppermost limit of calcareous rocks. The nature of the lower contact is not known. In the Rocky Mountain area the Upper Silurian and Middle Ordovician units appear to be conformable, but the contact was not seen, and they could be separated by a low-angle unconformity or disconformity (see also discussion "Middle Ordovician Rocks," above).

Calcareous rocks are associated with both the greenstone and the quartz latite. The volcanic rocks are mapped in four lenticular masses, each traceable on strike for 3 to $10 \mathrm{~km}$ and all apparently on essentially the same stratigraphic horizon. They range in composition from quartz latite to andesite. They are considerably altered, but remnant primary structures indicate that they originated as crystalline to glassy flows and locally as rudaceous volcaniclastic deposits. The source of the volcanic rocks is not established, but the unit appears to be thickest at Rocky Mountain, which suggests proximity to the eruptive center.

Slate is exposed along roads on Hafey Mountain, southwest of Rocky Mountain near Fox Pond, and on the main east-west access road, south of Chimenticook Stream (locally called "Sebemsecook" or "Chemsebemsecook" Stream). Calcareous siltstone is exposed on roads between East Branch, Pockwock Stream, and the junction of Shields Branch and Big Black River. Biostromal limestone was found only in the vicinity of Fivemile Brook, where it is associated with calcareous siltstone and greenstone.

Greenstone is well exposed along Fivemile Brook and in roads to the north as far as Twomile Brook. Quartz latite is well exposed at the base of the unnamed hill in the road along the East Branch, Pockwock Stream. Devitrified glass, probably quartz latite, is exposed on the crest and east slopes of Rocky Mountain, which is aptly named because the entire western flank is a continuous precipitous face of rock believed to be quartz latite volcanics; it was not traversed, however.

Dark-gray soft chalky-weathering slate and minor siltstone, graywacke, and calcareous sandstone compose a relatively thick sequence that is chiefly west of, and thus probably underlies, the calcareous and volcanic rocks. The slate is highly fissile and is the most erodable rock of the Upper Silurian unit. It was not studied in detail but is, in hand sample, indistinguishable from Lower 
Devonian gray slate described in a subsequent section. Calcareous and volcanic rocks appear to pinch out northeast of Rocky Mountain; the gray slate unit is inferred to extend as far northeast as Yankeetuladi Brook.

Light-greenish-gray to dark-gray, very fine to fine-grained, laminated to poorly bedded calcareous siltstone occurs above and below the greenstone and quartz latite. The rock weathers with a distinctive yellow-brown punky rind and is poorly fissile. Muscovite is conspicuous in hand sample, and the rock is commonly cut by calcite-quartz veinlets. In thin section, the rock shows textural and modal variations between slate and limestone. It is typically poorly sorted and is composed of about equal amounts of matrix and clasts. The matrix contains calcite, sericite, chlorite, quartz, and feldspar in variable amounts, and the clastic fraction contains equally variable amounts of quartz, chert, quartzite, feldspar, calcite, rock fragments, and muscovite; quartz commonly predominates. Shell fragments were observed in one section, and in another lithic clasts of volcanic rock fragments (similar to lithologies of the interbedded volcanic rocks), black slate, and chloritemuscovite phyllite were observed.

Medium- to dark-gray silty limestone containing abundant crinoid columnals and corals crops out prominently about $160 \mathrm{~m}$ downstream from the bridge over Fivemile Brook on the main access road from St. Pamphile, Quebec.

Two varieties of much-altered quartz latite are present. A laminated, spherulitic, dark-brownish-red, aphanitic to very fine grained, and conchoidally fractured variety occurs at Rocky Mountain. Weathered rock has a light-reddish-brown rind, and the abundant fracture surfaces are rusty. In thin section, radiating to felted patches of microlites and plagioclase are intergrown with crystals of potassic feldspar, quartz, chlorite, opaque minerals, and limonite. Blebs of quartz embayed by plagioclase euhedra are interspersed with the other minerals. Many quartz blebs contain boehm lamellae. An average estimated mode of the rock is given in table 3 . The lamination in the rock is probably relict primary flow structure.

Light-greenish-brown brecciated aphanite, which crops out beside the road along East Branch of Pockwock Stream, is the second variety of quartz latite. It also is believed to be a flow. Although this rock is modally similar to that at Rocky Mountain, it apparently was holocrystalline when it formed because it shows neither lamination nor spherulitic texture in thin section. The rock is composed of felted plagioclase laths as much as $0.33 \mathrm{~mm}$ 
PALEOZOIC STRATIGRAPHY

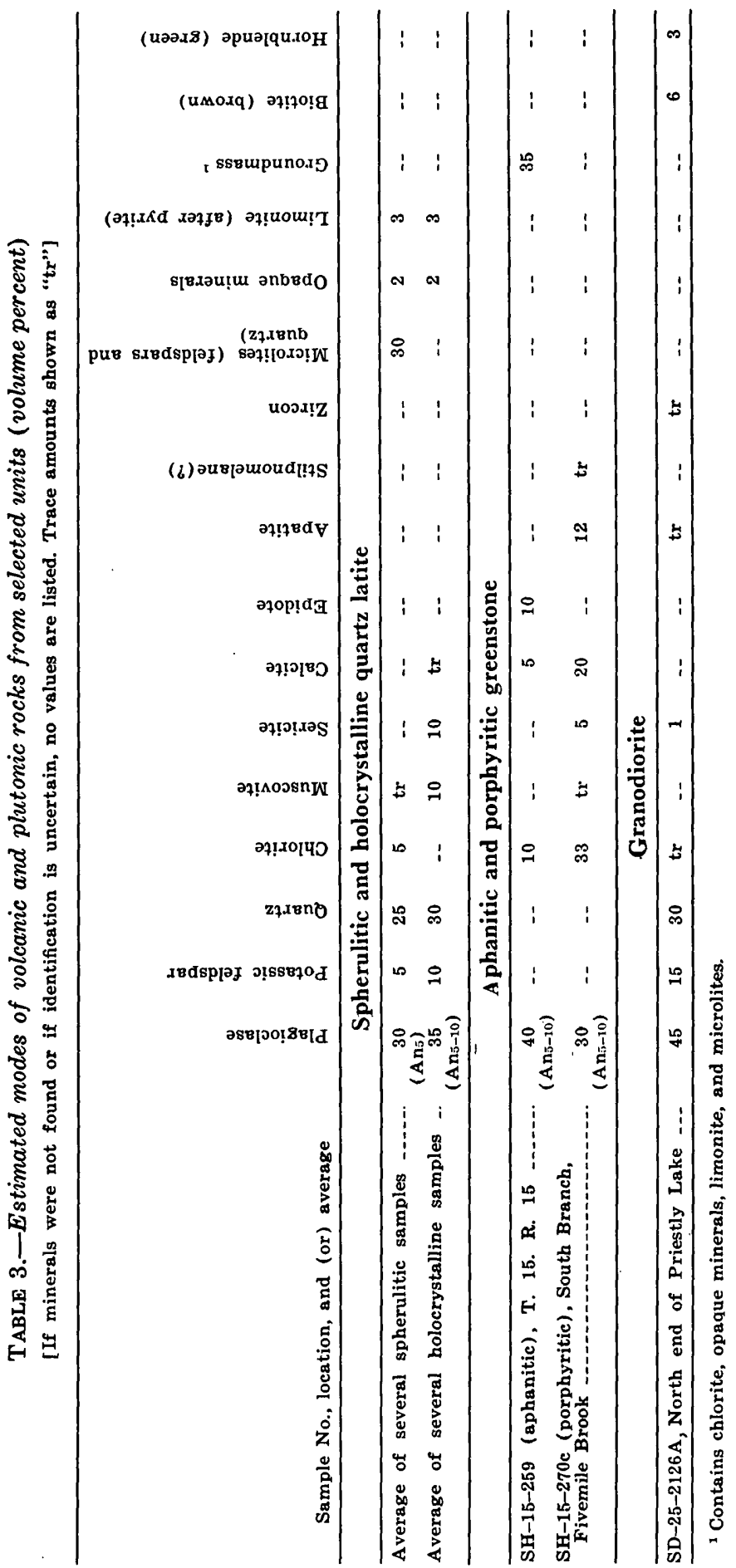


long intergrown with quartz, potassic feldspar, and muscovite. The estimated mode of this rock is given in table 3 .

Rocks mapped in the greenstone unit are more varied in texture than the quartz latite but are believed also to be effusive. Darkgreen aphanitic locally pillowed greenstone is most abundant. In places the rock is distinctly reddish (deuterically altered?). Such greenstone is interlayered with a coarse agglomerate composed of reddish volcanic rock fragments as much as $15 \mathrm{~cm}$ across in a dark-green matrix. Greenstone $6.4 \mathrm{~km}$ northeast of Fivemile Brook is more typical of the unit; it is dark greenish gray, fine grained, and massive. In thin section, felted to trachytic laths of plagioclase as much as $0.1 \mathrm{~mm}$ long are intergrown with chlorite and epidote in a groundmass of opaque minerals, limonite, chlorite, and microlites. Most of the groundmass appears to be devitrified glass. The rock is cut by calcite-quartz-epidote veinlets. The estimated mode is given in table 3 . Variations in the greenstone occur. A sample from Fivemile Brook downstream from the biostromal limestone is porphyritic but otherwise is similar in gross texture to the rock described above. The rock in Fivemile Brook, however, contains abundant chlorite that appears to be pseudomorphic after biotite or amphibole and also contains unusually abundant apatite. The abundance of phosphate cannot be presently explained. The estimated mode is given in table 3 . Both varieties of greenstone are probably derived from andesitic volcanic rocks.

At Rocky Mountain, about $1,100 \mathrm{~m}$ of Upper Silurian unit rocks are present, if a homoclinal easterly regional dip of $20^{\circ}$ is assumed. At Fivemile Brook no reliable indication of the regional dip is available, but as much as $1,600 \mathrm{~m}$ of Upper Silurian unit rocks may be present if the sequence dips vertically, as is suggested by the few bedding attitudes measured in the field.

\section{AGE AND GORRELATION}

Samples of the biostromal limestone examined by W. A. Oliver, Jr., of the U.S. Geological Survey have yielded the following identifiable forms.

Tabulate corals :

Favosites sp. (large corallites)

$F$. sp. (small corallites)

F. (Squameofavosites?) sp. (small corallites)

"Halysites" (probably Cystihalysites)

Heliolites sp.

Thamnopora sp. 
Rugose corals :

"Entelophyllum" sp. A. Stumm

Tryplasma nordica Stumm

Oliver reported that many of the species in this collection are found in the Hardwood Mountain Formation in Maine (Boucot, $1961)$ and the Mont Wissick Formation of Lespérance $(1960)^{2}$ in Quebec (see also Stumm and Oliver, 1962). On the basis of the fossils, the unit is here assigned a Late Silurian (Ludlovian) age.

\section{SILURIAN OR DEVONIAN ROCKS: STRATA OF THE ROCKY BROOK TERRANE}

\section{LITHOLOGY}

A poorly known sequence of rocks underlies a 6.4-km-wide tract between the belts of undivided Cambrian and Ordovician rocks and the Middle Ordovician rocks in the northwestern part of the area. This tract, called here the Rocky Brook terrane, extends northeastward across the area from Fivemile Brook to the vicinity of Jones Pond. Lithologies in the sequence include (1) massive greenish graywacke; (2) gray slate; (3) red and green slate; (4) red and green arkose; (5) feldspathic (volcaniclastic) cherty phyllite; (6) dark banded cherty argillite; and (7) fossiliferous calcareous quartzite and siltstone. Robert B. Neuman studied the fossiliferous rocks in 1963 and later described them to the authors (R. B. Neuman, oral commun., 1966, 1967). The graywacke, slates, arkose, quartzite, and siltstone are interbedded in various combinations.

Good exposures of graywacke, slates, arkose, quartzite, and siltstone may be seen on roads in the Rocky Brook, Beau Lake, and Little East Lake quadrangles (see pl. 1). The volcaniclastic rocks were observed at only one locality about $1.6 \mathrm{~km}$ northeast of the camp shown in the headwaters of Campbell Branch of the Little Black River (Campbell Depot), and cherty argillite was seen only on the east-trending shoulder about halfway between Jones Pond and Yankeetuladi Pond. The fossiliferous rocks were found only along the northwest-trending part of the access road west of Rocky Mountain.

The contacts of the unit were not seen, and we know little of their relationship to the adjacent pre-Silurian rocks. We infer in Sections $A-A^{\prime}$ and $B-B^{\prime}$ (pl. 1) that the Silurian and Devonian rocks form a synclinal outlier probably resting uncomformably

a The Mont Wissick Formation was elevated to the Mont Wissick Group by Lajoie and others, (1968). 
above Middle Ordovician rocks of the "Depot Mountain sequence." The northwestern contact is inferred to be a high-angle fault, the Silurian and Devonian rocks having been dropped down against older rocks of the "Estcourt Road sequence." This contact could be an unconformity. The southeast contact is inferred to be a thrust fault along which rocks of the "Depot Mountain sequence" moved northwest over the Silurian and Devonian rocks.

Although the volcaniclastic rocks and argillite are herein assigned to the Silurian or Devonian unit, they could equally well be older. The volcaniclastic rocks along the northwestern boundary of the unit are assigned to the Silurian or Devonian unit because they are southeast of the photointerpreted fault that apparently bounds the Silurian or Devonian unit on the northwest. The argil. lite has no obvious lithological counterpart in the region; thus, it is arbitrarily assigned to the strata of the Rocky Brook terrane and provisionally considered to be Silurian or Devonian.

The most widespread rock in the Silurian or Devonian unit is greenish-gray medium- to fine-grained graywacke that generally occurs in relatively massive beds more than $0.6 \mathrm{~m}$ thick. This rock is the most resistant of the sequence and holds up low ridges, which appear prominently in aerial photographs. In thin section, the rock is composed predominantly of subangular to rounded grains of quartz, feldspar, and lithic fragments (mainly volcanic rocks) set in a matrix of sericite, chlorite, calcite, and limonite. Thin-bedded graywacke, closely associated with the color-variegated slate, contains abundant muscovite. The average estimated mode is given in table 2.

Medium- to dark-gray slate is commonly interbedded with graywacke in subordinate amounts and locally is the predominant lithology. A large part of the Silurian or Devonian unit may be composed of slate which does not crop out well. Such slate is indistinguishable in the field from Lower Devonian slates described below. In outcrop the rock weathers into subangular chips, which differ from the predominantly flat chips that weather from outcrops of the Lower Devonian unit.

Variegated red and green arkose was observed in the central and southwestern parts of the unit. The rock appears to grade into graywacke and occurs in thick beds similar to those in the graywacke. The color varies from brick red to gray green in hand sample; the rock weathers to shades of reddish brown and buff. It is composed of poorly sorted angular to subrounded grains as much as $2 \mathrm{~mm}$ across of plagioclase, alkali feldspar, and quartz in a groundmass of sericite, limonite, chlorite, and quartz. Large 
grains of detrital zircon are conspicuous, and some of the quartz is rutilated. Estimated modes of two samples from the central part of the unit and from the southwest part of the unit are given in table 2.

Color-variegated slates are commonly associated with both the graywacke and the arkose. The slate varies from brick red to pale green; the green varieties weather dark olive to buff, and the red slates weather reddish brown.

Rock from the single occurrence of cherty phyllite near Campbell Depot is very fine to ultra-fine grained and pale greenish gray in hand sample. The rock varies from fissile to relatively massive depending upon grain size; it is silicified and is cut by a boxwork of quartz veins as much as $0.6 \mathrm{~cm}$ wide. Slip-cleavage deformation in the rock is locally intense. In thin section, the fine-grained rock is composed mainly of angular interlocking clasts of plagioclase and quartz as much as $0.01 \mathrm{~mm}$ across and minor amounts of clastic alkali feldspar, muscovite, opaque minerals, and zircon; sericite matrix is minor. The rock is locally intensely altered along slip-cleavage planes to a mixture of sericite and limonite, is cut by quartz-calcite veinlets, and is silicified. Finer grained beds are mainly a laminated mixture of sericite, limonite, quartz, and chlorite having sparse laminae containing minor plagioclase, quartz, and zircon clasts and devitrified volcanic fragments less than $0.01 \mathrm{~mm}$ across. Veinlets in the finer grained rock contain sulfide minerals. These rocks are volcaniclastic and consist of fine clastic material from a crystalline terrane that is mixed with volcanic material of detrital or airborne origin.

The single occurrence of cherty argillite in the Jones Brook area (Beau Lake quadrangle) was not studied in detail. It is texturally and compositionally somewhat similar to the Campbell Depot volcaniclastic rock. In hand sample the rock is dark to medium gray, characteristically banded to laminated, and sulfidic.

Medium- to coarse-grained dark-gray massive quartzite and punky-weathered green-gray siltstone occur along the road about $6.5 \mathrm{~km}$ northwest of the summit of Rocky Mountain. The quartzite weathers with an unusually whitish thin rind and is cut by quartz veinlets. To the east, the quartzite appears to grade into slaty siltstone.

A maximum thickness of $1,300 \mathrm{~m}$ is estimated for the Silurian or Devonian unit based on our interpretation of a synclinal inlier in this area (pl. 1 , secs. $A-A^{\prime}, B-B^{\prime}$ ) which is similar to the one mapped by Lespérance (1960) northeast of Lake Temiscouata (see also Neale and others, 1961, fig. 1). 


\section{AGE AND CORRELATION}

The shell fauna in calcareous siltstone from northwest of Rocky Mountain (pl. 1, locality F-117) consists of two or three pelecypod forms, two or three brachiopod forms, and one trilobite form. R. B. Neuman (oral commun., 1967) believed that the assemblage is probably of Silurian age, but it cannot be dated more closely than Silurian or Devonian. On the basis of a Silurian or Devonian age, this unit is tentatively correlated with the Upper Silurian Robitaille Formation of Lesperance (1960) and the Mont Wissick Group of Lajoie and others (1968) to the northeast. No equivalent rocks are described to the southwest, but Neale and others (1961, fig. 1; see also Poole, 1967, fig. 1) show a belt of Silurian and Devonian rocks on strike with the Silurian or Devonian unit terminating in Canada immediately across the International Boundary.

W. H. Poole (written commun., 1969) reported that the northeastward projection of this belt, possibly an outlier, is based upon a reinterpretation of conglomerate and sandstone ("St. Adalbert beds") which Béland (1957, p. 18-19) previously had placed in the Beauceville Group. Thus, the "St. Adalbert beds" are equated with Silurian and Devonian felsic volcanic rocks mapped by Béland (1957, p. 23-24) and the Silurian and Devonian "St. Luc beds" of conglomerate and white sandstone mapped by Gorman (1954).

\section{SILURIAN AND DEVONIAN ORTHOQUARTZITE UNIT: "HAFEY MOUNTAIN SEQUENCE"}

\section{LITHOLOGY}

Orthoquartzite interbedded with minor laminated sandstone and gray siltstone underlies a narrow belt between Hafey Mountain and Rocky Mountain. The unit is best exposed on the summit of Hafey Mountain and on the roads leading to it and, hence, is called the "Hafey Mountain sequence." The unit is very resistant and crops out well. At Hafey Mountain, the rock is brecciated. The orthoquartzite occurs in massive beds, probably more than $8 \mathrm{~m}$ thick. Locally the rock is conglomeratic, containing "pea gravel" quartz, chert, and rare quartzite clasts. Minor sandstone and siltstone beds do not crop out well and apparently compose less than 25 percent of the unit; these rocks were not studied in detail. The orthoquartzite is light brownish gray, granular, and laced with quartz veins. The rock weathers to light gray and has rusty fracture surfaces. In thin section, the rock is composed almost entirely of poorly to fairly well sorted angular grains of quartz $1 / 2$ to $2 \mathrm{~mm}$ 
across. Grain boundaries are interlocking and sutured, and rock from Hafey Mountain shows local cataclastic deformation manifested by crushing, mortar structure, and well-developed boehm lamellae in quartz grains. Some quartz clasts are strongly rutilated. The mode of sample S-1072 (pl. 1) from the summit of Hafey Mountain is given in table 2.

This rock contains sericite-limonite mixtures along shear planes which are bordered by crushed quartz. The orthoquartzite varies in modal character as shown in the estimated mode from sample S-2204 (table 2, pl. 1) taken on the road which crosses the unit about $0.8 \mathrm{~km}$ southwest of the Little Black River. The nature of the contact between these rocks and the dated Upper Silurian rocks to the northwest is not known. If, as is believed, the orthoquartzite unit was deposited in shallow water, perhaps as a beach deposit, its lower contact is probably an unconformity. From observations on the hillside southwest of Yankeetuladi Brook, the upper contact is believed to be gradational into Lower Devonian rocks. If this interpretation is correct, the unconformity at the base of the orthoquartzite does not necessarily establish an unconformity at the base of the Lower Devonian in the region because the age of the base of the orthoquartzite is not known; it could be Late Silurian.

The orthoquartzite unit is inferred to be tectonically repeated at Hafey Mountain where its maximum thickness probably occurs. An estimated thickness of $0-650 \mathrm{~m}$ is based upon the relationships at Hafey Mountain and an apparent pinchout southwest of Rocky Mountain.

\section{AGE AND CORRELATION}

The orthoquartzite, as mapped, occurs above known Upper Silurian and below known Lower Devonian rocks and is assumed to be Late Silurian and Early Devonian in age in the absence of more complete paleontologic data. No long-range correlations are attempted. The orthoquartzite is lithologically similar to rocks on regional strike to the northeast mapped by Lajoie (1963; Lajoie and others, 1966) as Val Brilliant Formation which is, however, dated as late Llandoverian to Wenlockian Age and therefore is older than the age indicated for the orthoquartzite at Hafey Mountain.

\section{SEBOOMOOK FORMATION LITHOLOGY}

Gray locally calcareous graywacke, gray slate, and cyclically bedded gray slate and sandstone of Early Devonian age form the 
most widespread unit in the upper St. John basin. These rocks are interbedded in variable proportions, but broad northeast-trending belts have been outlined in which one or another lithology predominates. Thick beds of graywacke characterize a zone at the base of the unit that extends from Beau Lake southwest to the southwest corner of the area. South and east of the Big Black River, belts of graywacke alternate with belts of gray slate and cyclically bedded gray slate and sandstone. Northeast of the Big Black River, the unit consists predominantly of cyclically bedded and graded gray slate and sandstone. Whether the alternating belts of graywacke, slate, and cyclically bedded rocks in the southeastern part of the region represent interfingering lithofacies or northeast-plunging folds, or both, is not known.

The graywacke is massive to crudely foliated, fine to medium grained, dark or greenish gray, and weathers light brown. Locally, where calcite is abundant, the rock weathers to a soft punkybrown rind about $2 \mathrm{~cm}$ thick. Beds of graywacke are generally resistant and form pronounced hogback ridges as much as $30 \mathrm{~m}$ wide. Thin lenses of gray slate are present locally. Graded bedding and crossbedding are rare.

The detrital fraction of the graywacke (table 2) is dominantly subrounded to subangular grains of quartz as much as $2 \mathrm{~mm}$ in diameter, plagioclase, alkali feldspar, and slate or phyllite fragments. Detrital flakes of muscovite as much as $2 \mathrm{~mm}$ in diameter are readily visible in hand specimen and thus serve to identify this rock. The detrital grains are set in a very fine grained matrix. Considerable variation exists in the relative abundance of matrix and stable and unstable grains. We were unable to establish in reconnaissance whether this variation is related to stratigraphic position, or what implications relative to the provenance of the unit are indicated.

Dark-green massive to highly fractured greenstone was seen at one locality within the graywacke south of Clayton Lake on the south edge of the area. The rock consists primarily of feldspar microlites, tremolite(?), epidote, chlorite, quartz, calcite, magnetite, and hematite and is laced with yellowish-green epidote-quartzcalcite veinlets. This greenstone could be either a flow or a sill.

Dark-gray soft chalky-gray weathering slate forms mappable zones as well as thinner beds in the graywacke. The slate is highly fissile and less resistant to erosion than the graywacke. It is composed primarily of quartz, albite, muscovite, and chlorite.

Northeast of the Big Black River cyclically bedded, locally graded bedded, gray slate and sandstone occur in which beds of 
sandstone $1 \mathrm{~cm}$ to $13 \mathrm{~cm}$ thick alternate with beds of gray slate of equal thickness. The slate is the same as that described above. The sandstone is composed primarily of angular to subangular grains of quartz ranging in size from fine sand to silt. Albite, muscovite, chlorite, pyrite, and locally calcite are present in subordinate amounts.

Near the Priestly Lake stock, described below, the gray slate and the cyclically bedded slate and sandstone are contact metamorphosed to a fine-grained dark-gray resistant andalusite-cordierite-biotite hornfels. Close to the intrusive body, the hornfels is equigranular and crossed by thin pods and stringers of quartz.

The Lower Devonian rocks (pl. 1) could possibly be as much as $6,500 \mathrm{~m}$ thick. A maximum thickness of $5,000 \mathrm{~m}$ for similar rocks on strike to the northeast is estimated by Jean Lajoie (oral commun., 1967). Boucot (1961, p. 71) estimated a thickness of 3,000$6,000 \mathrm{~m}$ for the Seboomook Formation in the Moose River synclinorium to the south and southwest. We, therefore, assume a thickness of about $5,000 \mathrm{~m}$ for the Seboomook in the reconnaissance area.

\section{AGE AND CORRELATION}

Shell fauna collections from localities F-11, F-300, and F-2027 have been examined by A. J. Boucot. The following forms have been identified.

F-11:

\section{Leptocoelia sp.}

F-300:

Acrospirifer murchisoni

Unidentified spiriferid

F-2027 (USNM loc. 13038) :

Platyorthis sp.

The sequence is assigned to the Early Devonian (Becraft-Oriskany) on the basis of the fossils and is thus correlated both paleontologically and lithologically with the Temiscouata Formation (Lespérance, 1960) to the northeast and to the Seboomook Formation (Boucot, 1961) and Ste. Juste Formation of Béland (Béland, 1957) to the south and southwest. Boucot (written communs., 1966 ) found that the fossils closely resemble previously identified forms in the Seboomook Formation.

\section{PRIESTLY LAKE STOCK}

A discordant stock of hornblende-biotite granodiorite underlies Priestly Lake and extends about $3 \mathrm{~km}$ north and east to the south- 
west side of Umsaskas Lake. The exposed part of the stock is about $1.2 \mathrm{~km}$ wide at Priestly Lake but may be as much as $3 \mathrm{~km}$ wide at Umsaskas Lake, where Kane and Bromery (1966) indicated a pronounced gravity low. The west contact of the stock is apparently steep, but contact metamorphism and many granodiorite dikes along the Lac Frontière-Churchill Road east of Priestly Lake suggest that the stock may underlie that area at a relatively shallow depth.

\section{LITHOLOGY}

The main body of the stock is composed of gray medium-grained equigranular granodiorite that is flecked with black where fresh, and dark brown to rusty tan where weathered. An average mode is given in table 3 . The plagioclase is zoned, and the alkali feldspar is perthitic.

At least one dark-gray to black porphyritic granodiorite(?) dike about $1 \mathrm{~m}$ wide cuts the main mass of the stock at the outlet to Priestly Lake. More than 70 percent of this rock is fine-grained matrix composed of feldspar and quartz(?). White euhedral to subhedral phenocrysts of plagioclase, ranging in length from about 0.5 to $5 \mathrm{~mm}$, make up about 15 percent of the rock. Black euhedral phenocrysts of hornblende as much as $3 \mathrm{~mm}$ long compose about 10 percent of the rock, and biotite phenocrysts generally less than $1 \mathrm{~mm}$ in diameter make up the remaining 2 or 3 percent of the rock.

Three unmapped dikes or sills as much as $8 \mathrm{~m}$ thick composed of light-gray to light-rusty-tan porphyritic granodiorite or quartz monzonite intrude the Lower Devonian rocks along the Lac Frontière-Churchill Road east of Priestly Lake. About 80 percent of this dike rock is a very fine grained groundmass of feldspar and quartz that contains phenocrysts of plagioclase, biotite, and hornblende in variable proportions. Plagioclase phenocrysts make up about 5 to 10 percent of the rock and range from fresh to highly sericitized. Fresh red-brown biotite composes 10 to 15 percent of the relatively unaltered rock and is pseudomorphically replaced by chlorite containing a rutile mesh in the altered rock. Hornblende ranges from less than 1 percent to about 3 percent and is locally altered to calcite, chlorite, and magnetite.

\section{AGE}

The Priestly Lake stock intrudes Lower Devonian rocks and thus must be Early Devonian in age or younger. It is probably of Middle or Late Devonian age but could be younger. 


\section{QUATERNARY DEPOSITS AND FEATURES}

Surficial deposits were examined and orientations of glacial striae on polished outcrops were measured incidental to the bedrock reconnaissance. Only a preliminary description of the extent and nature of the glacial deposits can be given. The striation pattern is sketchy and indicates that ice movement was generally in a south-southeasterly direction but had distinct local variations. Only relatively large stratified deposits are differentiated on plate 2 , and these are limited to the drainage of the Little Black River. The contacts of those deposits were inferred from features on aerial photographs. Other similar large stratified deposits may occur in the area, but they were not recognized in the field or on aerial photographs. The relative paucity of outcrops on the northwest sides of the hills suggests that the ice advanced from that direction and plastered relatively thick sections of till on those slopes.

\section{GLACIAL DRIFT}

A thin layer of glacial drift blankets most of the region. It is generally only a metre or so thick, but locally may be as much as $30 \mathrm{~m}$ thick on the stoss sides of slopes. The drift is composed primarily of loose, sandy till ("ground moraine") in which glacial erratics, largely from resistant rocks of the region are locally abundant. Minor amounts of thin stratified sand and gravel occur locally within the till. The till is so thin in much of the region that bulldozing operations for lumbering roads commonly expose bedrock. Borrow pits ${ }^{3}$ are found in both stratified and unstratified materials within the thicker, coarser grained parts of the drift. No good gravel deposits, such as those described in the following section, are found. The borrow exploited within the drift generally is suitable as road fill for lumbering operations.

\section{OUTWASH AND ICE-CONTACT DEPOSITS}

Deposits of stratified sand and fine- to medium-grained gravel are scattered throughout the region. Most of the outwash deposits appear to be relatively thin small lacustrine deltas. Kames or crevasse fillings, and one esker in the upper drainage of the Little Black River, compose the deposits of ice-contact origin. Two deposits at the north end of Rocky Mountain appear to be extensive and may contain appreciable volumes of good quality sand and

3 The use of the terms "borrow" and "borrow pits" conforms to the usage defined in (iary and others $(1972$, p. 85$)$. 
minor gravel. These deposits are believed to be lacustrine deltas. Extensive stratified deposits of sand and gravel as much as $8 \mathrm{~m}$ thick are abundant along the courses of the St. John and Allagash Rivers and are probably the largest such deposits in the region. Many of these deposits have been terraced by the rivers and are covered with thin fluvial sediments. Deposits along river courses appear to be both lacustrine deltas and kames.

\section{STRUCTURE}

The Silurian-Devonian rocks in the southeastern part of the map area are continuous with an extensive belt of Silurian-Devonian rocks included by Cady $(1960,1967)$ in the Connecticut ValleyGaspe synclinorium, and are assigned to the composite zone B/C subdivision of the Appalachian structural province (Williams and others, 1972, p. 184-185). Southeast of the St. John River basin, the Silurian-Devonian rocks are underlain by Cambrian(?) and Ordovician rocks of zone B/C exposed in several narrow northeastand north-trending anticlines that have been outlined and discussed by Pavlides and others (1964). In the northwestern part of the map area and continuing northwestward into Quebec, the Silurian-Devonian rocks give way to a broad tract of Cambrian and Ordovician rocks continuous with rocks of the Green Mountain-Sutton Mountain anticlinorium (Cady, 1960, 1967); these Cambrian and Ordovician rocks are assigned to the zone A subdivision of the Appalachian structural province (Williams and others, 1972, p. 184-185).

\section{FAULTS}

Our reconnaissance has shown that all the rocks in the region strike northeast and generally become younger from northwest to southeast. Seven new fossil localities, most of them in the critical area where the pre-Silurian and Silurian and Devonian rocks are juxtaposed, indicate that the Silurian rocks are not present everywhere beneath the Devonian rocks, suggesting either an unconformity between the pre-Silurian rocks and the younger rocks (see Lajoie and others, 1968, p. 621), or that parts of the section have been displaced by faults, or both. The distribution of the preSilurian, Silurian, and Devonian fossiliferous rocks cannot be satisfactorily explained by an unconformity alone. We propose, therefore, that a major fault system, with or without an unconformity beneath the Silurian or Devonian strata, accounts for the apparent juxtaposition of Lower Devonian and Middle Ordovician rocks in the southwest part of the area as well as for the ap- 
parent truncations of Middle Ordovician conglomerate and Upper Silurian calcareous and volcanic rocks in the upper Big Black River basin.

Lajoie and others (1968, fig. 2) interpreted a thrust fault (movement southeast over northwest) trending southwest toward Maine. If this fault, which places pre-Silurian rocks upon those of the Robitaille Formation, enters Maine, it does so essentially at the southeastern contact of the Rocky Brook terrane. On this basis, the Jones Brook thrust is inferred (pl. 1).

The Lower Devonian rocks, dated by fossil locality F-300 (pl. 1), are called the Bruleau Pond slice for the feature crossing the northwestern contact between the Middle Ordovician and Lower Devonian rocks. Fossiliferous Devonian rocks, found near Bruleau Pond (F-300, pl. 1), are on the southeast side of the belt of Middle Ordovician rocks (F-277 and F-2192, pl. 1) and appear to truncate a lens of Middle Ordovician polymictic conglomerate. To the east, Upper Silurian rocks (F-275, pl. 1) are also apparently truncated. Both of the truncations are inferred to be related to faults.

A major northeast-trending fault, called here the Rocky Mountain fault, is inferred to extend from the northern end of Beau Lake in the northeast at least as far as a point near Fivemile Brook in the southwest. Photolinears ${ }^{4}$ between Pockwock Stream and Yankeetuladi Brook (pl. 2) may be coincident with the northeastern part of this fault. Southwest of Fivemile Brook, this fault either follows a lineament across the mouth of Shields Branch to the east of Blood Lake or follows the contact between the Middle Ordovician and Lower Devonian rocks (as shown on pl. 1). On strike to the northeast near Rocky Mountain, various units of Middle Ordovician and Late Silurian age northwest of the Rocky Mountain fault are truncated by Upper Silurian and Lower Devonian rocks southeast of the fault. Although the actual fault plane is not exposed near Rocky Mountain, the truncation of northtrending rock units in the northwest wall by northeast-trending units in the southeast wall is clearly evident on aerial photographs.

The southeastern border of the Bruleau Pond slice is also a major fault that is either the southwestern extension of the Rocky Mountain fault or, as shown on plate 1, a second thrust, called here the Shields Branch thrust, which is mapped coincident with photolinears.

Fossiliferous Devonian rocks (loc. F-300, pl. 1) in the inferred Bruleau Pond slice are succeeded to the southeast across the

\footnotetext{
${ }^{4}$ See footnote 6 (p. 30 ).
} 
Shields Branch thrust by Middle Ordovician rocks, which in turn are overlain by the lenticular Silurian units exposed in Fivemile Brook at and near locality F-275. The contact between the Middle Ordovician rocks and the overlying Silurian units is inferred to be an unconformity, either Taconian (see Poole, 1967, p. 20) or younger (see Pavlides, 1972, on the "salinic break").

Many subsidiary faults, oriented parallel and oblique to the Rocky Mountain fault, are inferred from photolinears and the apparent offset of beds in the quartzite unit on Hafey Mountain and Rocky Mountain.

The reconnaissance nature of our mapping and the paucity of outcrops in much of the area make any interpretation of the fault system rather speculative. The interpretation shown on plate 1 indicates a major southeasterly dipping thrust (the Jones Brook thrust) and two essentially vertical faults (the Rocky Mountain and Dead Brook faults). These vertical faults can be either of simple normal displacement or of combined normal and strikeslip displacement; the Rocky Brook terrane is interpreted to be a fault-bounded syncline. Alternatively, the Dead Brook fault might dip southeast and be continuous with a northwest-dipping Jones Brook thrust. By this interpretation, the Rocky Brook terrane would be a klippe which would require an as-yet-unrecognized root zone, presumably to the southeast. Both hypotheses infer that the Silurian-Devonian rocks southeast of the Rocky Mountain fault are folded, probably in much greater detail than shown on plate 1 , at least as far southeast as the Hunnewell Lake lineament (pl. 2).

The trace of the Dead Brook fault bounding the northwest side of the terrane is believed to be coincident with the valley of Dead Brook, for which it is named, and the valley of Campbell Branch. A pronounced photolinear southwest of Rocky Brook may also be coincident with the inferred fault. Highly deformed and silicified rocks occur near the base of the undivided Silurian and Devonian rocks of the terrane and are believed to lie in or near the fault zone.

\section{FOLDS}

The inferred faulted syncline formed by the strata of the Rocky Brook terrane is possibly succeeded to the southeast by a tight overturned anticline in rocks of the Depot Mountain sequence along the Jones Brook thrust (see pl. 1, sec. $A-A^{\prime}$ ). Southeast of this anticline, the rocks of the Depot Mountain and Fivemile Brook sequences are in the northwest limb of a northeasterly plunging syncline which is dislocated by the Rocky Mountain fault. In the 
southwest part of the area, rocks of the Depot Mountain sequence are possibly folded into a regional anticline, and the rocks of the Seboomook Formation in the Bruleau Pond slice are possibly folded into a sycline, overturned to the northwest and cut by the Rocky Mountain and Shields Branch faults (pl. 1, see $C-C^{\prime}$ ). Axial traces of both of these folds appear to trend about N. $55^{\circ}$ E., and their axes probably plunge gently to the northeast. The rocks in the central belt of the area southeast of the Rocky Mountain fault or Shields Branch thrust appear to be in a southeast-facing homoclinal sequence. The pre-Silurian rocks of the "Lac Landry" and "Escourt Road" sequences in the northwestern part of the map area appear to be repeated in a major fold, though no direct evidence was found.

Opposite-facing graded beds mapped in the field and dip directions determined by photogeologic methods have outlined several folds in the slate and sandstone member of the Seboomook Formation southeast of the Rocky Mountain fault. Large roadcuts in these Lower Devonian rocks on strike to the northeast in Canada show chaotic and convolute minor folds of highly variable wavelength, which may have formed by wet-sediment deformation. The folds indicated by axial traces on plate 1 are thought to be open and symmetrical and probably plunge both northeast and southwest parallel to the plunges of the observed minor folds. The major folds range in wavelength from $700 \mathrm{~m}$ to several kilometres.

Throughout the Lower Devonian rocks in the map area, beds dip steeply and are locally overturned. Beds in the Silurian and Devonian rocks at Rocky Mountain dip less than $25^{\circ} \mathrm{E}$. Steeply dipping beds in the Devonian rocks may result from isoclinal minor folding, and the average overall dip of the major Lower Devonian lithologic units may be about $25^{\circ}$ to $30^{\circ}$, similar to the dips around Rocky Mountain.

Rocks in the undivided Cambrian and Ordovician unit contain more minor folds per unit area than the younger rocks and commonly contain two sets of minor folds having different orientations. The pre-Silurian rocks may have been deformed prior to Silurian time, but some of the minor folds may be related to faults.

\section{MINOR STRUCTURAL FEATURES}

Steeply dipping to vertical slaty cleavage, in places combined with fracture cleavage ${ }^{5}$ of variable dip, is particularly well de-

\footnotetext{
5 Cleavage and fold band (kink band) nomenclature herein follows the usage established by Albee and Boudette (1972, p. 73-78) (see also Gary and others, 1972).
} 
veloped in the Lower Devonian rocks and the pelitic beds of the older units. Fracture cleavage alone is more common in the competent quartzite units and in the volcanic rocks at Rocky Mountain. The volcanic rocks in the Fivemile Brook area, on the other hand, are quite massive. Foliation and bedding are commonly parallel or nearly so. Closely spaced foliation in the pelitic rocks produces a highly fissile slate or phyllite. Slaty cleavage is wider spaced, usually less than a millimetre, where present in arenaceous rocks and locally shows refraction (Albee and Boudette, 1972, p. 75). Spacing of fracture cleavage is more variable than that of the slaty cleavage and ranges from less than $1 \mathrm{~mm}$ to a few centimetres. Slaty cleavage is commonly earlier than fracture cleavage where both are present.

Two or more sets of cleavage having different orientations are common in rocks of the undivided Cambrian and Ordovician unit and are present in a few areas in the Middle Ordovician unit near the inferred faults. Where two cleavages are present, the slaty cleavage appears to have originated during the main period of folding because it commonly is parallel to the axial surfaces of minor folds, whereas the late cleavage, which is shallow dipping and has a markedly different strike, apparently formed after the rocks had been folded along northeast trends. It is possible that the late cleavage is, at least in part, related to the inferred faults.

Steeply dipping slip cleavage and fold bands are present in pelitic rocks in the southwestern part of the area. These structures, which are mainly within Lower Devonian rocks, vary in strike from northeast to nearly north and deform the slaty cleavage; they apparently formed after the regional folding.

Joints were rarely observed in outcrops of the foliated less competent rocks. Competent rocks, especially the Silurian and Devonian quartzite and the Upper Silurian volcanic rocks, however, are cut by closely spaced joints of various orientations. No regional sets or systems of joints were recognized, nor are any joints shown on plate 1.

\section{PHOTOLINEARS}

Many photolinears ${ }^{6}$ not related to cultural features were noted in the area. They vary from straight to markedly arcuate or sinuous

\footnotetext{
'Straight or curved lines formed by variations in photographic tone or color, or by alined shadows, define lineations visible on photographs, called here "photolinears," in order to differentiate them from the lineaments produced solely in the topography. The photolinears are not necessarily expressions of physiographic forms produced by systematic erosion of underlying structures, nor do they reflect, in all places, the areal distribution of lithologic or surficial units. Linear patterns can, in fact, be recorded on photographs in response to lighting phenomena such as shadow reinforcement effects or by the photographic process itself. Photolinears, excepting the Hunnewell Lake lineament, are not shown on plate 1 in the interest of clarity.
} 
traces, and their trends are both parallel to and across the regional strike. Many lineaments parallel to the regional trend of bedding and fold axes are clearly seen on the photographs to be minor cuestas. Several straight lineaments cut across valleys and are probably related to steeply dipping beds, faults, or sharp fold flexures related to fault traces.

A conspicuous set of northeast- and east-trending photolinears follows a narrow valley south of St. Francis that contains Hunnewell Lake and Bran Lake. This feature, which is here named the Hunnewell Lake lineament, appears to continue southwest to the junction of the Allagash and St. John Rivers and then west and southwest down Brown Brook just east of Fox Brook Rapids on the St. John River. On aerial photographs, the lineament clearly truncates the regional trend of bedding and major folds. It may, therefore, be related to a major fault, but our reconnaissance was not sufficient to determine the dip or movement on this hypothetical fault. It is tentatively shown on plate 1 , section $A-A^{\prime}$, as a fault.

\section{CONSTRUCTION MATERIAL}

Resources of rocks probably suitable as dimension stone, aggregate, and riprap, as well as sand and gravel, are shown on plate 2. Materials for impervious fill, such as dense silty till or clay, are not now known, but they might be found, particularly as till, on the northwestern sides of hills. Detailed mapping, exploration, and sampling are necessary to select sites for quarries and to determine the extent and composition of borrow material.

\section{DIMENSION STONE}

The Priestly Lake granodiorite is sufficiently massive to provide a local source of dimension stone. The rock is probably of acceptable strength, but high plagioclase and biotite content indicates that it may weather more readily than other granitic rocks quarried in New England and in nearby Canada.

\section{AGGREGATE}

The Upper Silurian rocks are believed to be an unusually promising source of aggregate. The limestone-bearing unit contains horizons that are relatively rich in carbonate and may provide rock of acceptable mechanical and chemical characteristics for concrete aggregate. Rocks of the same age and lithologic characteristics are quarried on strike to the northeast at Pied du Lac, Que- 
bec. Upper Silurian volcanic rocks vary considerably in chemical and mechanical characteristics and may provide local concentration of acceptable aggregate. The quartz latite from the Rocky Mountain-Pockwock Stream area is hard and brittle and would probably be suitable for concrete aggregate.

\section{RIPRAP AND COARSE FILL}

Silurian and Devonian quartzite, Upper Silurian volcanic rocks, Middle Ordovician polymictic conglomerate, and massive graywacke beds of Silurian and older age are potential sources of riprap and coarse fill. Except for the quartzite, the rocks are widely distributed in the region. The quartzite and volcanic rocks are more brittle than the others and probably could be quarried most efficiently. The quartzite and volcanic rocks also would provide more angular material that would have a more favorable reposeangle equilibrium than the conglomerate and graywacke, which contain a more pronounced foliation and would probably provide a slabby riprap material.

\section{SAND AND GRAVEL}

Sand and gravel deposits in the region are probably in excess of 250 million cubic yards. Brief examination of some of the existing borrow pits indicated that much of the material would have to be screened and washed to eliminate unstable clay, slate, and phyllite if it were used in construction of anything other than highway or railroad subgrade. The most promising large deposit of sand and gravel is within the lacustrine delta deposits north of Rocky Mountain and within the esker in the drainage of the Little Black River. (See pl. 2.) Alluvial deposits along the other major river courses probably contain similar but smaller volumes of sand and gravel.

\section{STREAM-SEDIMENT GEOCHEMISTRY}

Results of a geochemical reconnaissance of stream sediment in the upper St. John and Allagash basins are shown on plate 2. The data represent 263 analyzed samples of fine-grained sediment collected from the active channels of streams readily accessible by roads, trails, or waterways.

The samples were dried and screened through a 250-micron sieve. The minus-250-micron portions were analyzed for cold citrate-soluble heavy metals (principally undifferentiated copper, lead, and zinc) and for cold acid-extractable copper by rapid semiquantitative field methods described by Ward and others (1963, 
p. 25-29). The mercury content of 31 samples was determined photometrically.

\section{HEAVY METALS AND COPPER}

A statistical study of the distribution of the citrate-soluble heavy-metal values revealed that 2 percent exceed a value of 14 parts per million ( $\mathrm{ppm}$ ) and may be considered anomalous. Previous experience and similar studies on the distribution of cold acidextractable copper elsewhere in Maine (Post and Hite, 1963) suggested that values exceeding $2 \mathrm{ppm}$ are possibly anomalous and are worth field checking. Plate 2 shows only raw data; we did not investigate the possible significance of apparently anomalous values. The sulfide minerals, pyrite and possibly pyrrhotite, are known only at Depot Mountain.

Many heavy-metal anomalies found in stream-sediment surveys elsewhere in Maine are associated with appreciable concentrations of manganese and iron oxides, which are efficient scavengers of many heavy metals, especially zinc. The 263 samples collected in this area were not analyzed for manganese. Therefore, these apparent heavy-metal anomalies should be interpreted cautiously because they may reflect only scavenging by manganese oxides.

\section{MERCURY}

Little is known of the geochemistry of mercury in stream sediments; therefore, the interpretation of the data presented here is preliminary. The range in mercury values is from less than $0.010 \mathrm{ppm}$ to $0.150 \mathrm{ppm}$; the distribution follows:

\begin{tabular}{|c|c|c|c|}
\hline Value & range $(p p m)$ & Samples & Percent \\
\hline $\begin{array}{r}0.010-0.040 \\
.050-.080 \\
.090-.100 \\
.110-.150\end{array}$ & 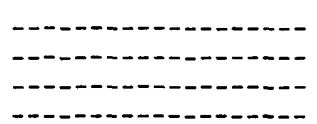 & $\begin{array}{r}22 \\
2 \\
5 \\
2\end{array}$ & $\begin{array}{c}71 \\
6.5 \\
16 \\
6.5\end{array}$ \\
\hline
\end{tabular}

The distribution of the analyzed sediments suggests that higher mercury values tend to be associated with higher heavy-metals and copper values in a northeast-trending belt within the Seboomook Formation in the middle of the region. This association, however, may simply reflect a higher amount of organic material in the samples (E.V. Post, written commun., -1967). Post speculated that organic matter may interfere with the mercury analysis. F. C. Canney (written commun., 1967) speculated that both mercury and total heavy metals are scavenged by manganese or organic matter. Canney believed that some organic decomposition products are absorbed on the gold trap with the mercury and, 
because these products absorb ultraviolet light in the detection system, as does mercury, they are recorded as mercury, and hence give erroneously high values for mercury. Although little can be concluded from the mercury values at this time, the data are included on plate 2 for possible future use.

\section{ROCK GEOCHEMISTRY}

Six rock samples from the Silurian and Devonian orthoquartzite, the orthoquartzite in the undifferentiated Paleozoic unit, and

TABLE 4.--Rapid 6-step spectrographic analyses and instrumental mercury analyses of selected rocks from the upper St. John basin, Maine

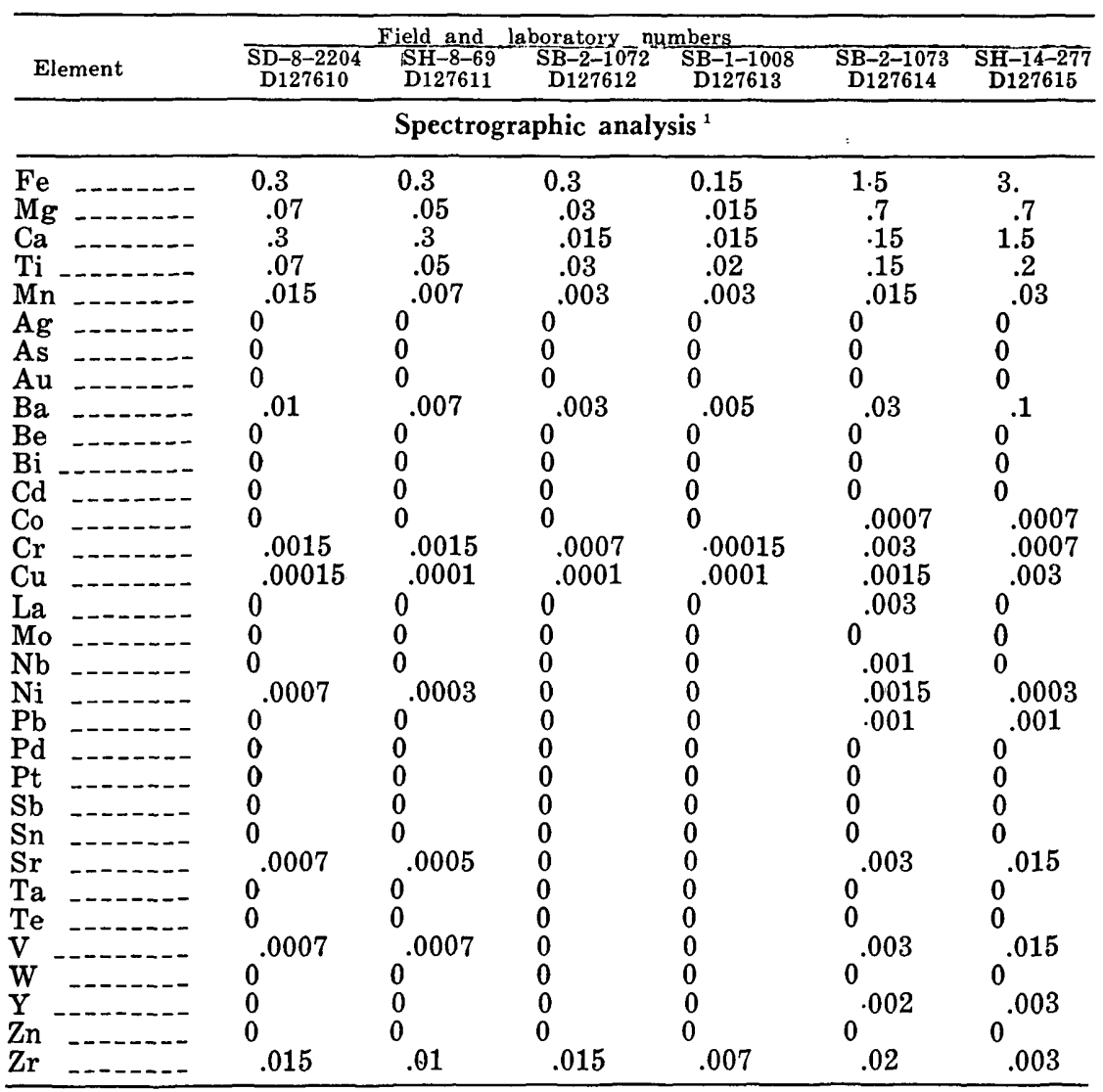

Instrumental mercury analysis (ppm)

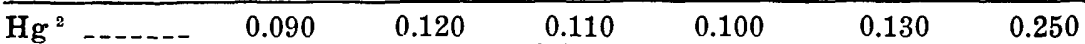

$\mathrm{Au}^{3}$...... All below limit of detectability at 0.020

1 Analyst: J. C. Hamilton $(2 / 15 / 67)$. Results are reported in percent to the nearest number in the series $0.3,0.2,0.15$, and 0.1 , etc. which represent the approximate midpoints of interval data on a geometric scale. The assigned interval for semiquantatative results will include the qualitative value about 30 percent of the time. $0=$ looked for, but not detected in the range of detectability.

inalyst: R. Hansen (4/25/67)

3 Analysts: $Z$. Stephenson and T. Ging (4/12/67). 
the Middle Ordovician conglomerate were selected for standard spectrographic analysis by the rapid 6-step method (Shapiro and Brannock, 1962) and for mercury determination. These samples (located on plate 1) are representative of units considered to be possible source rocks for the heavy metals detected in the streamsediment samples. Sample S-277 (same as SH-14-277, table 4) from Depot Mountain contained visible pyrite.

The results of the laboratory studies are given in table 4 and show no anomalous values of metals in the samples. The distribution of the samples is, however, too scattered to rule out the possibility that rocks from other parts of these lithologic units, or other units not sampled, may be mineralized.

\section{SELECTED REFERENCES}

Albee, A. L., and Boudette, E. L., 1972, Geology of the Attean quadrangle, Somerset County, Maine: U.S. Geol. Survey Bull. 1297, 110 p.

Bailey, L. W., 1887, On the Silurian system of northern Maine, New Brunswick, and Quebec: Royal Soc. Canada Trans., v. 4, p. 35-41.

Bailey, L. W., and McInnes, W., 1888, Report on explorations and surveys in portions of northern New Brunswick and adjacent areas in Quebec and Maine, U.S.: Canada Geol. Survey Ann. Rept. 3, 1887-1888, Rept. M, $52 \mathrm{p}$.

1893, Report on portions of the province of Quebec and adjoining areas in New Brunswick and Maine relating more especially to the counties of Temiscouata and Rimouski, P.Q.: Canada Geol. Survey Ann. Rept. 5, 1890-1891, Rept. M, 28 p.

Béland, Jacques, 1957, St. Magloire and Rosaire-St. Phamphile areas-electoral districts of Dorchester, Bellechasse, Montmagny and L'Islet: Quebec Dept. Mines, Geol. Surveys Br. Geol. Rept. 76, 49 p.

1962, Ste-Perpétue area: Quebec Dept. Nat. Resources, Geol. Rept. 98, $22 \mathrm{p}$.

Berry, W. B. N., 1962, On the Magog, Quebec, graptolites: Am. Jour. Sci., v. 260 , no. 2 , p. $142-148$.

Boucot, A. J., 1961, Stratigraphy of the Moose River synclinorium, Maine: U.S. Geol. Survey Bull. 1111-E, p. 153-188.

Boucot, A. J., Griscom, Andrew, and Allingham, J. W., 1964, Geologic and aeromagnetic map of northern Maine: U.S. Geol. Survey Geophys. Inv. Map GP-312.

Cady, W. M., 1960, Stratigraphic and geotectonic relationships in northern Vermont and southern Quebec: Geol. Soc. America Bull., v. 71, p. 531576.

1967, Geosynclinal setting of the Appalachian Mountains in southeastern Quebec and northwestern New England, in Clark. T. H., ed., Appalachian tectonics: Royal Soc. Canada Spec. Pub. 10, p. 57-68.

Gary, Margaret, McAfee, Robert, Jr., Wolf, C. L., eds., 1972, Glossary of geology: Washington, D.C., Am. Geol. Inst., 857 p.

Gorman, W. A., 1954. Preliminary report on Ste. Justine area-Montmagny, Bellechasse and Dorchester counties: Quebec Dept. Mines, Geol. Surveys Br. Prelim. Rept. no. 297, 5 p. 
1955, Preliminary report on St. Georges-St. Zacharie area-Beauce and Dorchester counties: Quebec Dept. Mines, Geol. Surveys Br. Prelim. Rept. no. 314, 6 p.

Hitchcock, C. H., 1861a, General report upon the geology of Maine, in Holmes, Ezekiel and Hitchcock, C. H., 1861, Preliminary report upon the natural history and geology of the State of Maine: Maine Board Agricuture, 6th Ann. Rept. Augusta, Maine, p. 146-328.

1861b, Geology of the wild lands [Maine], in Holmes, Ezekiel, and Hitchcock, C. H., 1861, Preliminary report upon the natural history and geology of the State of Maine: Maine Board Agriculture, 6th Ann. Rept., Augusta, Maine, p. 377-419.

_ 1862, Geology of Maine (includes contributions by G. L. Goodale, Oliver White, and Ezekiel Holmes), in Holmes, Ezekiel, and Hitchcock, C. H., 1862, Second annual report upon the natural history and geology of the State of Maine: Maine Board Agriculture 7th Ann. Rept., Augusta, Maine, p. 223-430.

Hodge, J. T., 1838, On the Allagash section from the Penobscot to the St. Lawrence River, in Jackson, C. T., Second annual report on the geology of the public lands belonging to the two States of Maine and Massachusetts: Augusta, Maine, p. 49-73.

Hubert, Claude, 1967, Tectonics of part of the Sillery Formation in the Chaudière-Matapédia segment of the Quebec Appalachians, in Clark, T. H., ed., Appalachian tectonics: Royal Soc. Canada Spec. Pub. 10, p. 33-40.

- ed., 1969, Flysch sediments in parts of the Cambro-Ordovician sequence of the Quebec Appalachians, in Guidebook, Flysch sedimentology in the Appalachians: Geol. Assoc. Canada Guidebook for Field Trip No. 1, Montreal, June 5-7, 1969, 38 p.

Hubert, Claude, Lajoie, Jean, and Léonard, M. A., 1970, Deep sea sediments in the Lower Paleozoic Quebec Supergroup, in Lajoie, Jean, ed., Flysch sedimentology in North America: Geol. Assoc. Canada Spec. Paper 7, p. 103-125.

Jackson, C. T., 1838, Second report on the geology of the State of Maine: Augusta, Maine, $168 \mathrm{p}$.

Kane, M. F., and Bromery, R. W., 1966, Simple Bouguer gravity map of Maine: U.S. Geol. Survey Geophys. Inv. Map GP-580.

Lajoie, Jean, 1963, The Siluro-Devonian stratigraphy in the central Matapedia-Témiscouata region: Montreal, McGill Univ., unpub. Ph.D. thesis, 192 p.

Lajoie, Jean, Lespérance, P. J., and Béland, Jacques, 1966, Silurian stratigraphy and paleogeography of the Matapedia-Témiscouata region, Quebec: Maritime Sediments, v. 2, no. 2, p. 73-75.

1968, Silurian stratigraphy and paleogeography of Matapedia-Témiscouata region, Quebec: Am. Assoc. Petroleum Geologists Bull., v. 52, no. 4 , p. 615-640.

Lespérance, P. J., 1960, The Silurian and Devonian rocks of the Témiscouata region, Quebec: Montreal, McGill Univ., unpub. Ph.D. thesis, 264 p.

MacKay, B. R., 1921, Beauceville map area, Quebec: Canada Geol. Survey Mem. 127, 105 p.

McGerrigle, H. W., 1934. Western Témiscouata: Quebec Bur. Mines, Ann. Rept. 1933, pt. D, p. 105-145. 
Neale, E. R. W., Béland, Jacques, Potter, R. R., and Poole, W. H., 1961, A preliminary tectonic map of the Canadian Appalachian region based on age of folding: Canadian Mining and Metall. Bull., v. 54, no. 593, p. 687694.

Pavlides, Louis, 1972, Geologic map of the Smyrna Mills quadrangle, Aroostook County, Maine: U.S. Geol. Survey Geol. Quad. Map GQ-1024.

Pavlides, Louis, Mencher, Ely, Naylor, R. S., and Boucot, A. J., 1964, Outline of the stratigraphic and tectonic features of northern Maine, in Geol. Survey Research 1964: U.S. Geol. Survey Prof. Paper 501-C, p. C28C38.

Poole, W. H., 1967, Tectonic evolution of Appalachian region of Canada, in Neale, E. R. W., and Williams, Harold, eds., Collected papers on geology of the Atlantic region: Geol. Assoc. Canada Spec. Paper 4, p. 9-51.

Post, E. V., and Hite, J. B., 1963, Heavy metals in stream sediment, westcentral Maine: U.S. Geol. Survey Mineral Inv. Field Studies Map MF278 [revised 1964].

St-Julien, Pierre, 1967, Tectonics of part of the Appalachian region of southeastern Quebec, in Clark, T. H., ed., Appalachian tectonics: Royal Soc. Canada Spec. Pub. 10, p. 41-47.

Shapiro, Leonard, and Brannock, W. W., 1962, Rapid analysis of silicate, carbonate, and phosphate rocks: U.S. Geol. Survey Bull. 1144-A, p. A1A56.

Stumm, E. C., and Oliver, W. A., Jr., 1962, Silurian corals from Maine and Quebec: U.S. Geol. Survey Prof. Paper 430, 31 p.

Ward, F. N., Lakin, H. W., Canney, F. C., and others, 1963, Analytical methods used in geochemical exploration by the U.S. Geological Survey: Geol. Survey Bull. 1152, 100 p.

Williams, Harold, Kennedy, M. J., Neale, E. R. W., and others, 1972, The Appalachian structural province, in Price, R. A., and Douglas, R. J. W., eds., Variations in tectonic styles in Canada: Geol. Assoc. Canada Spec. Paper 11, p. 181-261.

Williams, Howel, Turner, F. J., and Gilbert, C. M., 1954, Petrography: San Francisco, W. H. Freeman and Co., 406 p.

Wing, L. A., 1951, Geological reconnaissance of the St. John and Allagash River valleys, in Maine Geol. Survey, Rept. State Geologist, J. M. Trefethen, 1949-50: Augusta, Maine, Maine Devel. Comm. p. 61-67. 